\title{
ANTI-INFLAMMATORY PROPERTIES OF PAVETTA CRASSICAULIS BREMEK. LEAF AND FLOWER CRUDE EXTRACTS AND ITS PURE COMPOUNDS COLLECTED FROM WESTERN GHATS, KARNATAKA, INDIA
}

\author{
ASHWATHANARAYANA R*, RAJA NAIKA \\ Department of PG Studies and Research in Applied Botany, Jnanasahyadri, Kuvempu University, Shimogga - 577 451, Karnataka, India. \\ Email: ashwinjamadagni497@gmail.com
}

Received: 09 August 2018, Revised and Accepted: 26 May 2018

ABSTRACT

Objective: Pavetta crassicaulis Bremek. (F: Rubiaceae) plant extracts were subjected to anti-inflammatory experiment by using carrageenin-induced rat hind paw edema method.

Methods: Groups of 5 rats of both sexes (pregnant females excluded) were given a dose of the extract. After $1 \mathrm{~h}, 0.1 \mathrm{ml}, 1 \%$ carrageenan suspension in $0.9 \% \mathrm{NaCl}$ solution was injected into the subplantar tissue of the right hind paw. Paw volume was measured plethysmometrically at $0 \mathrm{~h}$ and $3 \mathrm{~h}$ after carrageenin injection.

Results: Anti-inflammatory experiments revealed that, the leaf and flower ethanolic extract of the $P$. crassicaulis Bremek. plant shown excellent antiinflammatory and its extracted pure compounds, 2-tert-butyl-4,6-bis(3,5-di-tert-butyl-4-hydroxybenzyl)phenol and 4H-pyran-4-one,2,3-dihydro3,5dihydroxy-6-methyl- is a pure compound isolated from the Pavetta crassicaulis flower extract. showed excellent anti-inflammatory activity compared with the standard.

Conclusion: P. crassicaulis Bremek. leaf and flower could be exploited as a valuable source of anti-inflammatory agent for the pharmaceutical industry.

Keywords: Pavetta crassicaulis Bremek., Western Ghats, Karnataka, Anti-inflammatory, 2-tert-butyl-4,6-bis(3,5-di-tert-butyl-4-hydroxybenzyl) phenol, 4H-pyran-4-one,2,3-dihydro-3,5-dihydroxy-6-methyl-.

(c) 2018 The Authors. Published by Innovare Academic Sciences Pvt Ltd. This is an open access article under the CC BY license (http://creativecommons. org/licenses/by/4. 0/) DOI: http://dx.doi.org/10.22159/ajpcr.2018.v11i9.21885

\section{INTRODUCTION}

Medicinal plants are the richest bioresources for many types of medicinal practices such as modern medicines, Allopathy, Homeopathy, Naturopathy, Unani, Acupuncture, Ayurveda, nutraceuticals, folk medicines, synthetic drugs and pharmaceuticals, intermediate, food supplements [1].

Indian subcontinent is a vast repository of medicinal plants that are used in traditional medical treatments which also forms a rich source of knowledge [2]. India is one of the megadiversity centers in the planet having a diverse medicinal plant species which is unexplored most of them are endemic. India shares approximately $13 \%$ of world's biodiversity, one among 17 megadiversity centers. Among the 34 hotspots in the world, India has 4 hotspots, namely, Eastern Himalaya, Indo-Burma, Western Ghats, Andaman and Nicobar Island. The various indigenous systems use several plant species to treat different ailments [3]. In India, around 20,000 medicinal plant species have been recorded recently, but more than 500 traditional communities use about 800 plant species for curing different diseases [4].

Western Ghats is a mountain range that runs parallel to the western coast of the Indian peninsula, located entirely in India. The range starts near the border of Gujarat and Maharashtra, runs approximately $1600 \mathrm{~km}$ through the states of Maharashtra, Goa, Karnataka, Kerala, and Tamil Nadu ending at Kanyakumari, at the southern tip of India [5].

Experimental medicinal plant and description:

Pavetta crassicaulis Bremek. Scientific classification:

Kingdom: Plantae

Division: Magnoliophyta

Class: Magnoliopsida
Subclass: Asteridae

Family: Rubiaceae

Order: Rubiales

Genus: Pavetta

Species: P. crassicaulis Bremek.

P. crassicaulis Bremek. is an important ethnomedicinal shrub or small tree belonging to the family Rubiaceae, grows up to $4 \mathrm{~m}$ tall, the plant is endemic to peninsular India. The leaves are often membranous with dark bacterial nodules, has small, white, tubular flowers, sometimes salviform or funnel-shaped with 4 spreading petal lobes. The flowers are carried on terminal corymbs or cymes, the leaves are elliptical-oblong to elliptic-lanceolate, $6-15 \mathrm{~cm}$ long, and pointed at both ends. The flowers are white, rather fragrant, and borne in considerable number in hairy terminal panicle which is $6-10 \mathrm{~cm}$ long. The sepals are very small and toothed. The flowers tube is slender and about $1.5 \mathrm{~cm}$ long, with obtuse petals above half the length of the tube. The fruits are black when they dry, somewhat rounded and about $6 \mathrm{~mm}$ in diameter [6].

P. crassicaulis Bremek. endemic to peninsular India and distributed in many places such as Mizoram, Gujarat, Uttara Pradesh, Chhattisgarh, Orissa Maharashtra, and Karnataka [7-10].

P. crassicaulis Bremek. has medicinal properties which is used in many parts of India, Pavetta plant parts used in the treatment of arthritis, boils and itches, hemorrhoidal pains, visceral problems, dropsy [11], epilepsy, hemorrhoids [12], skin diseases [13], anticephalagic, fat burner, aphrodisiac [14], urinary complaints and fruits used as anthelmintic and flowers are eaten fried [15].

The preliminary qualitative phytochemical analysis of $P$. crassicaulis Bremek. methanolic crude extract revealed the presence of 
alkaloids, steroids, and terpenoid with moderate antimicrobial activity $[16,17]$.

The present study focused on the anti-inflammatory properties of P. crassicaulis Bremek. plant parts.

\section{METHODS}

\section{Plant collection and authentication}

The bark and leaf materials of $P$. crassicaulis Bremek. were collected from Shringeri taluk, Karnataka in April 2014 (13.4198 N, 75.2567 E) (Fig. 1). The plant was identified by Prof. K G Bhat, Udupi, and a voucher specimen was conserved under the reference number $\mathrm{KU} / \mathrm{AB} / \mathrm{RN} /$ AS/001.

\section{Plant preparation and extraction}

The samples were dried in the shade for 20-25 days, mechanically powdered, and subjected to Soxhlet extraction using petroleum ether, chloroform, and ethanol [18]. The crude extracts were collected in airtight plastic containers and stored in cool condition.

\section{Preliminary phytochemical screening}

Air-dried and powdered leaf materials and also all crude extracts were screened for the presence of tannins, alkaloids, saponin, glycosides, flavonoids, steroids/sterols, and phenols using standard methods [19-21].

\section{Gas chromatography and mass spectroscopy (GC-MS) analysis}

Pavetta crassicaulis Bremek leaf and flower ethanolic extracts were subjected to GC-MS analysis and obtained spectra was analysed. GC model: Thermo Trace GC Ultra, MS Model: Thermo DSQ II, Ionization: Electron impact ionization (EI), chemical ionization (CI), mass range: $1-1074 \mathrm{~m} / \mathrm{z}$.

\section{Isolation of pure compound}

The stationary phase in column chromatography is silica gel and the mobile phase or eluent is the mixture of different immiscible solvents [22]. $5 \mathrm{~g}$ of residue is dissolve in ethanol and it will adsorbed on to the silica gel powder and of $150 \mathrm{~g}$ is loaded to column. The column was eluted with $n$-hexane $100 \%$, flowed by $n$-hexane and ethyl acetate

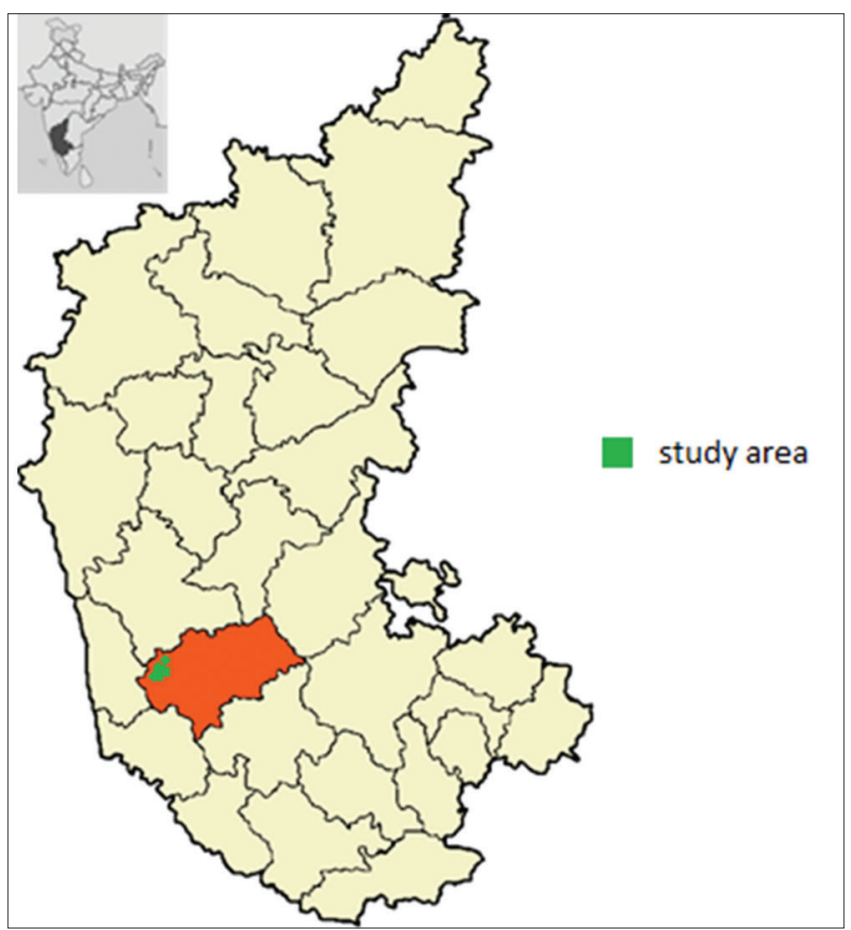

Fig. 1: Sampling site details and location in different ratios $(99: 1,90: 10,80: 20,60: 40,50: 50)$ and followed by ethyl acetate $100 \%$ and the with mixture of ethyl acetate:ethanol (99:1, 98:2, 95:5, 90:10, 80:20). Simultaneously, the same elution is monitored by thin-layer chromatography (TLC) (silica gel and for visualization, mixture of vanillin: Sulfuric acid heated at $110^{\circ} \mathrm{C}$ ). Each time, $5 \mathrm{ml}$ were collected and TLC monitored same elute was concentrate to $5 \mathrm{ml}$ stored in the refrigerator.

\section{Rat maintenance}

Rats (120-170 g) of either sex kept at the laboratory Animal home of the Faculty of Pharmacy, SCS College of Pharmacy, Harapanahalli, Davanagere, were used. The animals were maintained under standard environmental conditions and had free access to standard diet and water. Plant extracts were administered orally by gavage in distilled water at different dose levels. All experiments were carried out according to the Institutional Animal Ethics Committee Guidelines (Re: SCSCP/IAEC/11/12/2016-17)

Anti-inflammatory activity by carrageenin-induced rat hind paw edema method (in vivo model)

Anti-inflammatory activity was measured using carrageenan-induced rat paw edema assay $[23,24]$. Groups of 5 rats of both sexes (pregnant females excluded) were given a dose of the extract. After $1 \mathrm{~h}, 0.1 \mathrm{ml}$, $1 \%$ carrageenan suspension in $0.9 \% \mathrm{NaCl}$ solution was injected into the subplantar tissue of the right hind paw. Paw volume was measured plethysmometrically at $0 \mathrm{~h}$ and $3 \mathrm{~h}$ after carrageenin injection [25]. Two groups of drug-treated rats and one control group were used each test day, the mean paw edema value for the test group being compared with its mean value for the control group for that day. The test compounds $(50 \mathrm{mg} / \mathrm{kg}$ ) were administered orally; standard group was treated with diclofenac $(50 \mathrm{mg} / \mathrm{kg})$ orally $1 \mathrm{~h}$. before by injection and control group received only vehicle. Mean difference in paw volume was measured and percentage inhibition was calculated by following formula.

$$
\% \text { inhibition of edema }=\frac{V c-V t}{V c} \times 100
$$

Where $\mathrm{Vt}=$ mean paw volume of test group. $\mathrm{Vc}=$ mean paw volume of control group.

Anti-inflammatory activity [26] was measured as the percentage reduction in edema level when drug was present, relative to control.

\section{Statistical analysis}

All data were validated with the help of statistical software PRISM and MINITAB; the values were expressed as mean \pm standard error of the mean and results were statistically analyzed by one-way analysis of variance (ANOVA) followed by Dunnet's t-test. Symbols represent statistical significance. ${ }^{*} \mathrm{p}<0.05,{ }^{* *} \mathrm{p}<0.01,{ }^{* * *}<0.0001 \mathrm{~ns}-$ not significant, as compared to control group.

\section{RESULTS}

\section{Extract yield and preliminary phytochemical analysis}

The Soxhlet extraction of $P$. crassicaulis Bremek. leaf $(750 \mathrm{~g})$ with petroleum ether gives $12.32 \mathrm{~g}$, with chloroform gives $19.99 \mathrm{~g}$, and with ethanol gives $75.35 \mathrm{~g}$ yield. The results of preliminary qualitative phytochemical screening of different extracts of $P$. crassicaulis Bremek. leaf indicate the presence of saponins, tannins, flavonoids, steroids/ sterols, glycosides, and phenols in ethanolic crude extract and chloroform extract confirms the presence of phenols and sterols and petroleum extracts negative results for all the phytochemical tests.

The Soxhlet extraction of $P$. crassicaulis Bremek. flower $(750 \mathrm{~g})$ with petroleum ether gives $20.34 \mathrm{~g}$, with chloroform gives $18.64 \mathrm{~g}$ and with ethanol gives $45.38 \mathrm{~g}$ yield. The results of phytochemical screening of $P$. crassicaulis Bremek. flower extracts indicate the presence of alkaloids, saponins, flavonoids, steroids/sterols, glycosides, and phenols in 
ethanol crude extract, the chloroform crude extracts shows positive results for flavonoids. However, the petroleum ether crude extract gave negative results for all these compounds (Table 1).

\section{GC-MS analysis of ethanolic crude extract}

\section{Leaf ethanolic extract}

In GC-MS analysis of medicinal P. crassicaulis Bremek., ethanolic leaf extract revealed the presence 34 compounds, in that major percentage of compounds present was 2-tert-butyl-4,6-bis(3,5-di-tert-butyl-4hydroxybenzyl)phenol (38.84\%), cyclo\{tetra[(5-t-butyl-2-hydroxy-1,3phenylene)methylene]\} (15.72\%), 4H-pyran-4-one, 2,3-dihydro-3,5dihydroxy-6-methyl- (9.34\%), bicyclo[3.3.1]nona-3,7-diene-2,9-dione (6.25\%), and methyl ester of bicyclo[4.3.0]non-1(6)-en-4,7-dione-8carboxylic acid (5.66\%). The major compound 2-tert-butyl4,6-bis(3,5di-tert-butyl-4-hydroxybenzyl)phenol (37.44\%) have antioxidant properties and also used as ultraviolet stabilizer. Cyclo\{tetra[(5-t-butyl2-hydroxy-1,3-phenylene)methylene]\} (15.72\%), 4H-pyran-4-one,2,3dihydro-3,5-dihydroxy-6-methyl- (9.34\%) has antioxidant properties (Table 2 and Figs. 2-4).

\section{Flower ethanolic extract}

The GC-MS analysis of $P$. crassicaulis Bremek. flower ethanolic extract revealed the presence of 39 compounds, in that, $4 \mathrm{H}$ pyran- 4one,2,3-dihydro-3,5-dihydroxy-6 methyl- (13.82\%), benzaldehyde, 2-methyl- (7.25\%), benzaldehyde, 2 hydroxy-6-methyl- (6.52\%), 2 -furancarboxaldehyde, and 5-(hydroxymethyl)-(6.30\%) in major percentage. and campesterol also $(0.80 \%)$, stigmasterol $(0.62 \%)$, B.Sitosterol (3.10\%) in meagre percentage (Figs.5-7 and Table 3).

\section{Column chromatography of ethanolic leaf and flower extract}

\section{Leaf ethanolic extract}

Elution carried out with n-hexane in 100\% concentration eluted compound 1 in small quantity and with n-hexane:ethyl acetate at the ratio 80:20 gives compound 2, but its yield is too less. Ethyl acetate was eluted mixture of many compounds and ethyl acetate:ethanol at 80:20 yielded large quantity of compound 3 . The gradient of other residues was yielded mixture of compound which is confirmed by TLC therefore not subjected to further process.

Compound 3L was yielded more so, we took only compound 3L for further structural analysis.

The pure compound 3L was crystalline transparent grayish color. Further, the pure compound subjected to cNMR, hNMR, infrared (IR), mass spectral analysis, and the molecular formula was $\mathrm{C}_{40} \mathrm{H}_{58} \mathrm{O}_{3}$, molecular weight $586.887 \mathrm{~g} / \mathrm{mol}$. From all these details, the compound name was found to be tert-butyl-4,6-bis(3,5-di-tert-butyl-4-hydroxybenzyl)Phenol (Figs. 8-11).

Table 1: Preliminary phytochemical analysis of different extract of $P$. crassicaulis Bremek. leaf and flower

\begin{tabular}{|c|c|c|c|c|c|c|c|}
\hline \multirow[t]{2}{*}{ Secondary metabolites } & \multirow[t]{2}{*}{ Type of tests } & \multicolumn{2}{|c|}{$\begin{array}{l}\text { Petroleum ether } \\
\text { crude extract }\end{array}$} & \multicolumn{2}{|c|}{$\begin{array}{l}\text { Chloroform } \\
\text { crude extract }\end{array}$} & \multicolumn{2}{|c|}{$\begin{array}{l}\text { Ethanol } \\
\text { crude extract }\end{array}$} \\
\hline & & Leaf & Flower & Leaf & Flower & Leaf & Flower \\
\hline \multirow[t]{2}{*}{ Alkaloids } & Mayer's test & - & - & - & - & - & - \\
\hline & Wagner's test & - & - & - & - & - & - \\
\hline Saponins & Foam test & - & - & - & - & + & + \\
\hline Tannins & Ferric chloride test & - & - & - & + & + & + \\
\hline \multirow[t]{4}{*}{ Flavonoids } & Shinda test & - & - & - & - & + & + \\
\hline & Zinc- $\mathrm{HCl}$ reduction test & - & - & - & - & + & + \\
\hline & Alkaline reagent test & - & - & - & - & + & + \\
\hline & Lead acetate test & - & - & - & + & + & + \\
\hline Steroids & Salkowaski test & - & - & - & - & + & + \\
\hline \multirow[t]{3}{*}{ Glycosides } & Keller-Killiani's test & - & - & - & - & + & + \\
\hline & Brown water test & - & - & - & - & + & + \\
\hline & Legal test & - & - & - & - & + & + \\
\hline Phenols & Ferric chloride test & - & - & + & - & + & + \\
\hline
\end{tabular}

-: Negative result, +: positive result. P. crassicaulis: Pavetta crassicaulis

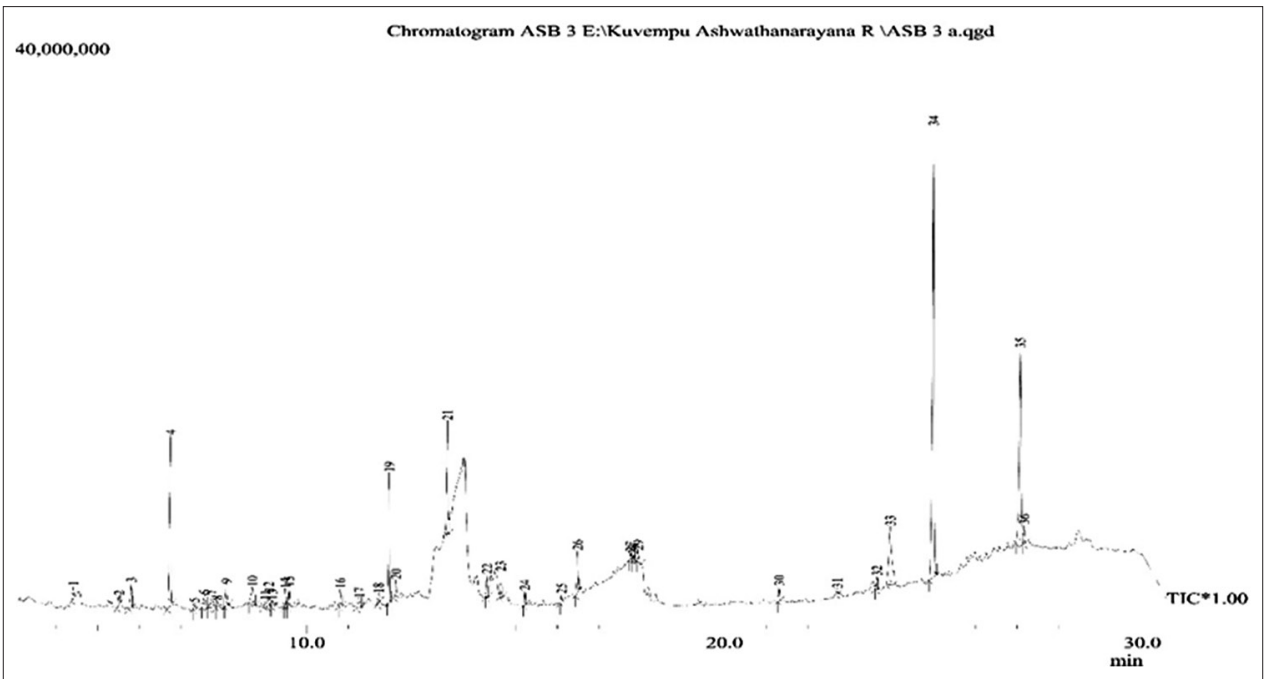

Fig. 2: Gas chromatography and mass spectroscopy chromatogram of leaf ethanolic extract of Pavetta crassicaulis Bremek. 
Table 2: Presence of metabolites in GC-MS analysis of crude ethanolic extract of $P$. crassicaulis Bremek. leaf collected from Western Ghats Karnataka

\begin{tabular}{|c|c|c|c|}
\hline Sl. No & Chemical compound present & Average percentage & Properties of the compound \\
\hline 1 & 2,4-dihydroxy-2,5-dimethyl-3 (2H)-furan-3-one & 0.53 & Food-grade flavor ingredients [30] \\
\hline 2 & 2,5-dimethyl-4-hydroxy-3 (2H)-furanone & 0.52 & Flavor and perfume industry [31] \\
\hline 3 & 2-hexanone, 3-methyl-4-methylene- & 1.45 & Paint and paint thinner [32] \\
\hline 4 & 4H-pyran-4-one, 2,3-dihydro-3,5-dihydroxy-6-methyl- & 9.34 & $\begin{array}{l}\text { Mutagen antimicrobial, anti-inflammatory, and } \\
\text { antioxidant capacity [27-29] }\end{array}$ \\
\hline 5 & $\begin{array}{l}\text { 4-[4-chlorophenyl]-N-[2-[1-methyl-2-pyrrolidinyl] } \\
\text { ethyl]-6-[trichloromethyl]-2-pyrimidine }\end{array}$ & 1.14 & Unknown \\
\hline 6 & 2,3-dihydro-benzofuran - & 1.35 & $\begin{array}{l}\text { Entactogen drug of the phenethylamine and } \\
\text { amphetamine classes, cytotoxic [33] }\end{array}$ \\
\hline 7 & 2-furancarboxaldehyde, 5-(hydroxymethyl)- & 0.66 & $\begin{array}{l}\text { Food additives, antimicrobial, preservative, } \\
\text { flavoring agents }[34,35]\end{array}$ \\
\hline 8 & 1,2,3-propanetriol, 1 -acetate & 1.46 & Unknown \\
\hline 9 & 6-oxoheptanoic acid & 1.53 & $\begin{array}{l}\text { 6-oxoheptanoic acid is a reagent to synthesize } \\
\text { new penicillin containing keto acids as side } \\
\text { chains. It is also used to study the various } \\
\text { metabolic pathways of } 4 \text {-hydroxypentanoate } \\
\text { and levulinate [36] }\end{array}$ \\
\hline 10 & Benzaldehyde, 4-hydroxy- & 0.47 & Flavor and fragrance agents [37] \\
\hline 11 & 2-Methoxy-4-vinylphenol & 1.14 & $\begin{array}{l}\text { Flavoring agent, antibacterial activity, } \\
\text { anti-inflammatory effect }[38,39]\end{array}$ \\
\hline 12 & Phenol, 2-methoxy-4-(2-propenyl)- & 0.39 & $\begin{array}{l}\text { Flavoring agent used in the manufacture of } \\
\text { vanillin, antiinfective agents, antioxidant }[40,41]\end{array}$ \\
\hline 13 & 2,4-dimethyl-3-nitrobicyclo[3.2.1]octan-8-one & 0.78 & $\begin{array}{l}\text { Oils obtained from myrrh and frankincense and } \\
\text { parthenium weed have little percentage }[42,43]\end{array}$ \\
\hline 14 & rac-2,4-dimethyl-3-nitrobicyclo[3.2.1]octan-8-one & 0.96 & Unknown \\
\hline 15 & Benzaldehyde, 2-hydroxy-6-methyl- & 0.98 & $\begin{array}{l}\text { Pheromone of the acarid mite Tyrophagus } \\
\text { perniciosus and grain mite Aleuroglyphus } \\
\text { ovatus }[44,45]\end{array}$ \\
\hline 16 & $2(3 \mathrm{H})$-naphthalenone, 4,4a, 5,6-tetrahydro- & 0.77 & Unknown \\
\hline 17 & 1,5-diazocine, octahydro-1,5-dinitro- & 0.40 & Unknown \\
\hline 18 & $\begin{array}{l}\text { Methyl ester Of bicyclo[4.3.0] } \\
\text { non-1 (6)-en-4,7-dione-8-carboxylic acid }\end{array}$ & 5.66 & Unknown \\
\hline 19 & $\begin{array}{l}\text { Acetic acid, (2-isopropenyl cyclopentylidene)-, methyl } \\
\text { ester }\end{array}$ & 0.83 & Unknown \\
\hline 20 & Bicyclo[3.3.1]nona-3,7-diene-2,9-dione & 6.25 & Unknown \\
\hline 21 & 4-((1E)-3-Hydroxy-1-propenyl)-2-methoxyphenol & 1.32 & $\begin{array}{l}\text { Antimicrobial, antioxidant, anti-inflammatory, } \\
\text { analgesic [34] }\end{array}$ \\
\hline 22 & 2-methyl-5-(4-methylphenyl) tetrazole & 0.71 & Unknown \\
\hline 23 & $\begin{array}{l}\text { 2-hexadecen-1-ol, 3,7,11,15-tetramethyl-, [R-[R*, } \\
\mathrm{R}^{*} \text {-(E)]]- }\end{array}$ & 1.12 & $\begin{array}{l}\text { Antimicrobial, anticancer, antiinflammatory, } \\
\text { diuretic, cytotoxic, flavoring agents, used in the } \\
\text { preparation of vitamins E and K1. It is also a } \\
\text { decomposition product of chlorophyll, used in } \\
\text { the treatment of arthritis }[28,46,47]\end{array}$ \\
\hline 24 & Hexadecanoic acid, methyl ester & 0.29 & Perfumes and cosmetics [48] \\
\hline 25 & Hexadecanoic acid & 2.04 & $\begin{array}{l}\text { Perfumes, cosmetics, enzyme inhibitors, } \\
\text { surfactants, flavoring agents, adhesives } \\
\text { and sealant chemicals, agricultural } \\
\text { chemicals (non-pesticidal), fillers, finishing agents, } \\
\text { intermediates, lubricants and lubricant additives, } \\
\text { surface active agents, antiandrogenic flavor, } \\
\text { hemolytic, 5-alpha reductase inhibitor }[49,50]\end{array}$ \\
\hline 26 & Octanal, 7-methoxy-3,7-dimethyl- & 0.37 & Unknown \\
\hline 27 & 9,12,15-octadecatrienoic acid, methyl ester, (Z, Z, Z)- & 0.28 & $\begin{array}{l}\text { Antibacterial, Anti-inflammatory, } \\
\text { hypocholesterolemic, cancer preventive, } \\
\text { hepatoprotective, nematicide, insectifuge, } \\
\text { antihistaminic, antieczemic, antiacne, } \\
\text { 5-alpha reductase inhibitor, antiandrogenic, } \\
\text { anti-arthritic, anticoronary, insectifuge [28] }\end{array}$ \\
\hline 28 & $\begin{array}{l}\text { Hexadecanoic acid, 2-hydroxy-1-(hydroxymethyl) ethyl } \\
\text { ester }\end{array}$ & 0.62 & $\begin{array}{l}\text { Wound healing activity, hemolytic, pesticide, } \\
\text { flavor, antioxidant [51] }\end{array}$ \\
\hline 29 & $\begin{array}{l}\text { 9,12-Octadecadienoic acid (Z, Z)-, } \\
\text { 2-hydroxy-1-(hydroxymethyl) ethyl ester }\end{array}$ & 0.30 & $\begin{array}{l}\text { Hypocholesterolemic, nematicide, } \\
\text { anti-arthritic, hepatoprotective, antiandrogenic, } \\
\text { hypocholesterolemic, nematicide, 5-alpha } \\
\text { reductase inhibitor, anti-histaminic, anticoronary } \\
\text { insectifuge, anti-eczemic, anti-acne [52] }\end{array}$ \\
\hline
\end{tabular}


Table 2: (Continued)

\begin{tabular}{llll}
\hline Sl. No & Chemical compound present & Average percentage & Properties of the compound \\
\hline 30 & $\begin{array}{l}2,6,10,14,18,22-T e t r a c o s a h e x a e n e, \\
2,6,10,15,19,23-h e x a m e t h y l-\end{array}$ & 0.52 & $\begin{array}{l}\text { Bactericide, antifungal, cytotoxic, antibacterial, } \\
\text { antioxidant, antitumor, cancer preventive, } \\
\text { immunostimulant, chemopreventive, } \\
\text { lipoxygenase-inhibitor, perfumery, pesticide, } \\
\text { and sunscreen [53] } \\
\text { Unknown }\end{array}$ \\
31 & $\begin{array}{l}\text { 2-tert-butyl-4,6-bis (3,5-di-tert-butyl-4-hydroxybenzyl) } \\
\text { phenol }\end{array}$ & 38.84 & Unknown \\
32 & $\begin{array}{l}\text { Cycl } \text { \{tetra[(5-t-butyl-2-hydroxy-1,3-phenylene) } \\
\text { methylene]\} } \\
\text { Stigmast-5-en-3-ol, (3.beta.,24S)- }\end{array}$ & 15.72 & $\begin{array}{l}\text { Antimicrobial antioxidant, Anti-inflammatory } \\
\text { anti-arthritic, anti-asthma, diuretic [54] }\end{array}$ \\
\hline
\end{tabular}

GC-MS: Gas chromatography and mass spectroscopy, P. crassicaulis: Pavetta crassicaulis

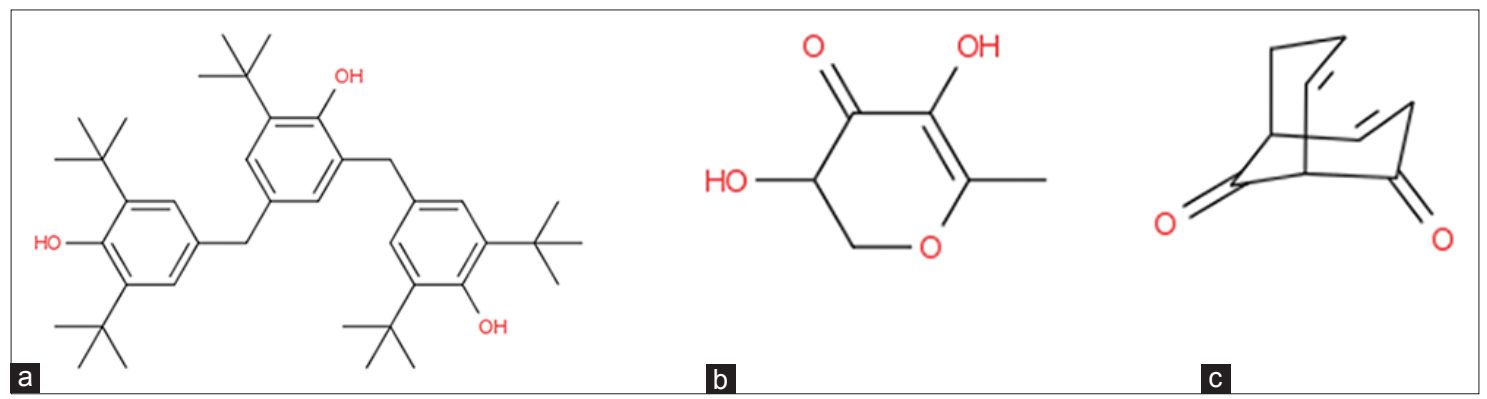

Fig. 3: Major constituents in gas chromatography and mass spectroscopy analysis of crude ethanolic extract of Pavetta crassicaulis Bremek. leaf. (a) 2-tert-butyl-4,6-bis(3,5-di-tert-butyl-4-hydroxybenzyl)phenol, (b) 4H-pyran-4-one,2,3-dihydro-3,5-dihydroxy-6-methyl-, (c) Bicyclo[3.3.1]nona-3,7-diene-2,9-dione

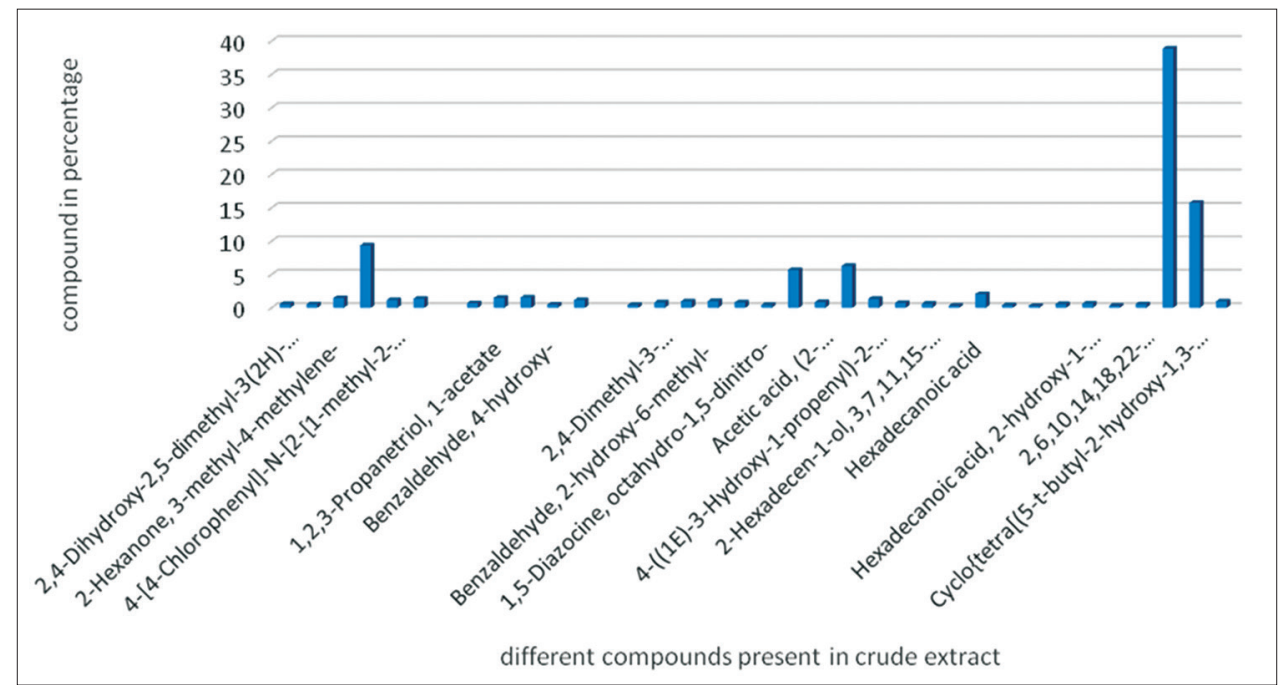

Fig. 4: Gas chromatography and mass spectroscopy of crude Pavetta crassicaulis Bremek. ethanolic leaf extract showing percentage of different compounds

\section{Flower ethanolic extract}

Elution carried out with n-hexane in $100 \%$ concentration eluted nil compound and with n-hexane:ethyl acetate at the ratio 90:10 gives compound 1, but its yield is too less. Ethyl acetate was eluted compound 2 and ethyl acetate:ethanol at 90:10 yielded large quantity of compound 3. The gradient of other residues was yielded mixture of compound which is confirmed by TLC therefore not subjected to further process.

Compound $3 \mathrm{~F}$ was yielded higher quantity so we took only compound $3 \mathrm{~F}$ for further structural analysis.
The pure compound 3F was crystalline light brown colored and shiny surface. Further, it was subjected to cNMR, hNMR, IR, and mass spectral analysis and the molecular formula was found to be $\mathrm{C}_{6} \mathrm{H}_{8} \mathrm{O}_{4}$, molecular weight $144.1253 \mathrm{~g} / \mathrm{mol}$, from all these details the compound name was found to be 4H-pyran-4-one,2,3-dihydro-3,5-dihydroxy-6methyl- (Figs. 12-15).

Anti-inflammatory activity of different extract of $P$. crassicaulis Bremek Anti-inflammatory activity of leaf crude extracts

The extracts were tested at three different dose levels to know if they were dose-dependent. From the results obtained, it is revealed 


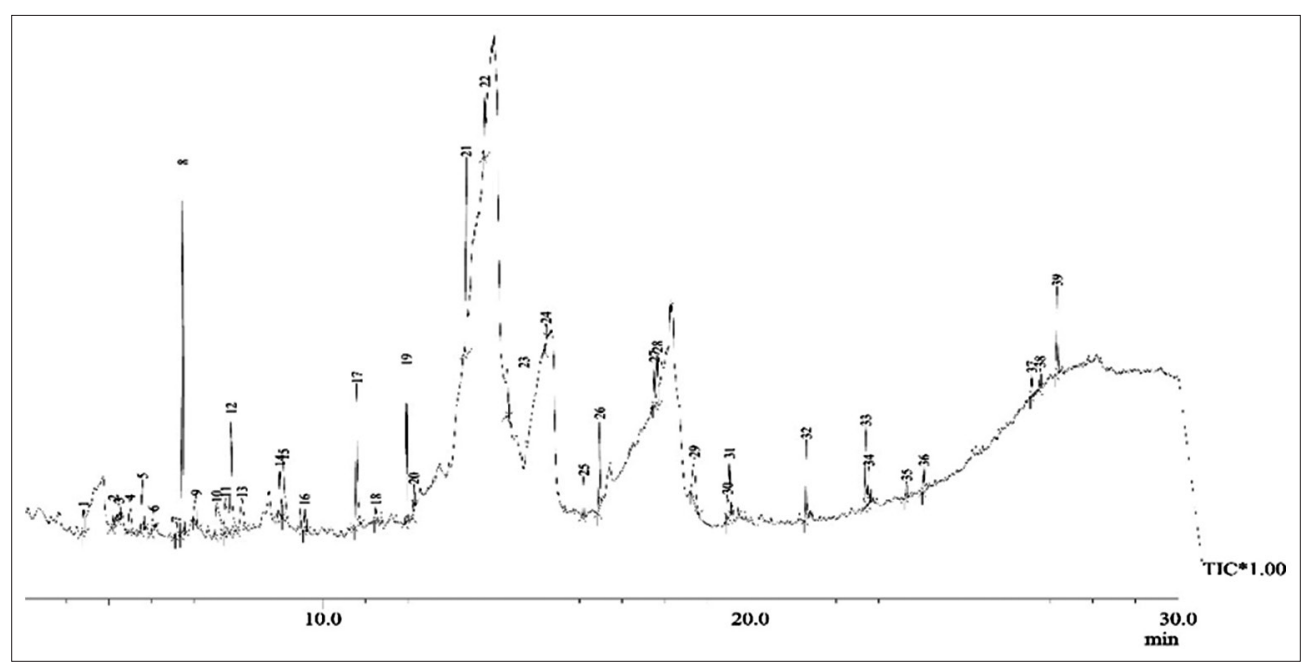

Fig. 5: Gas chromatography and mass spectroscopy chromatogram of flower ethanolic extract of Pavetta crassicaulis Bremek.

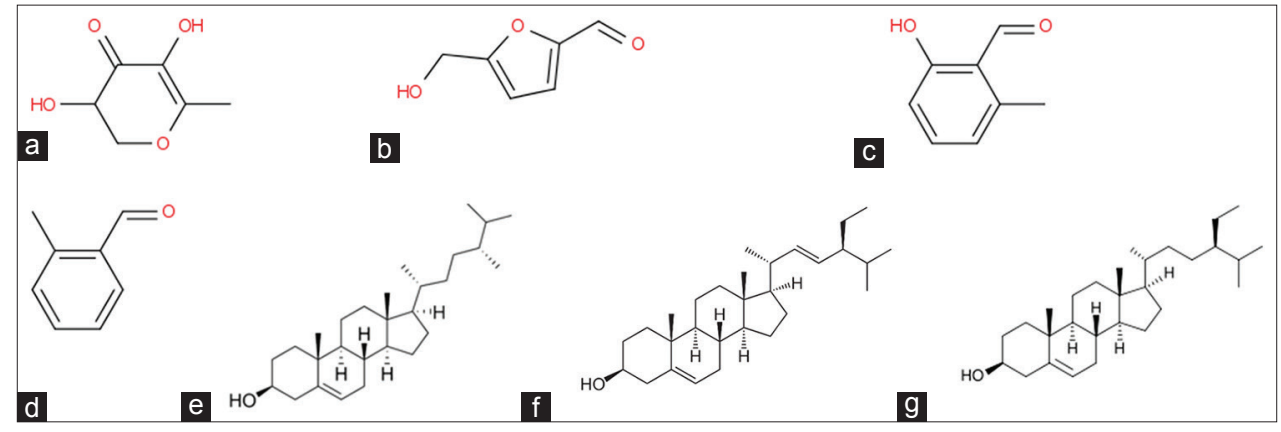

Fig. 6: Major constituents in gas chromatography and mass spectroscopy analysis of crude ethanolic extract of Pavetta crassicaulis Bremek. flower. (a) 4H-pyran-4-one, 2,3-dihydro-3,5-dihydroxy-6-methyl-, (b) 2-furancarboxaldehyde, 5-(hydroxymethyl)-,

(c) Benzaldehyde, 2-hydroxy-6-methyl-, (d) Benzaldehyde, 2-methyl-, (e) Campesterol, (f) Stigmasterol, (g) $\beta$-Sitosterol

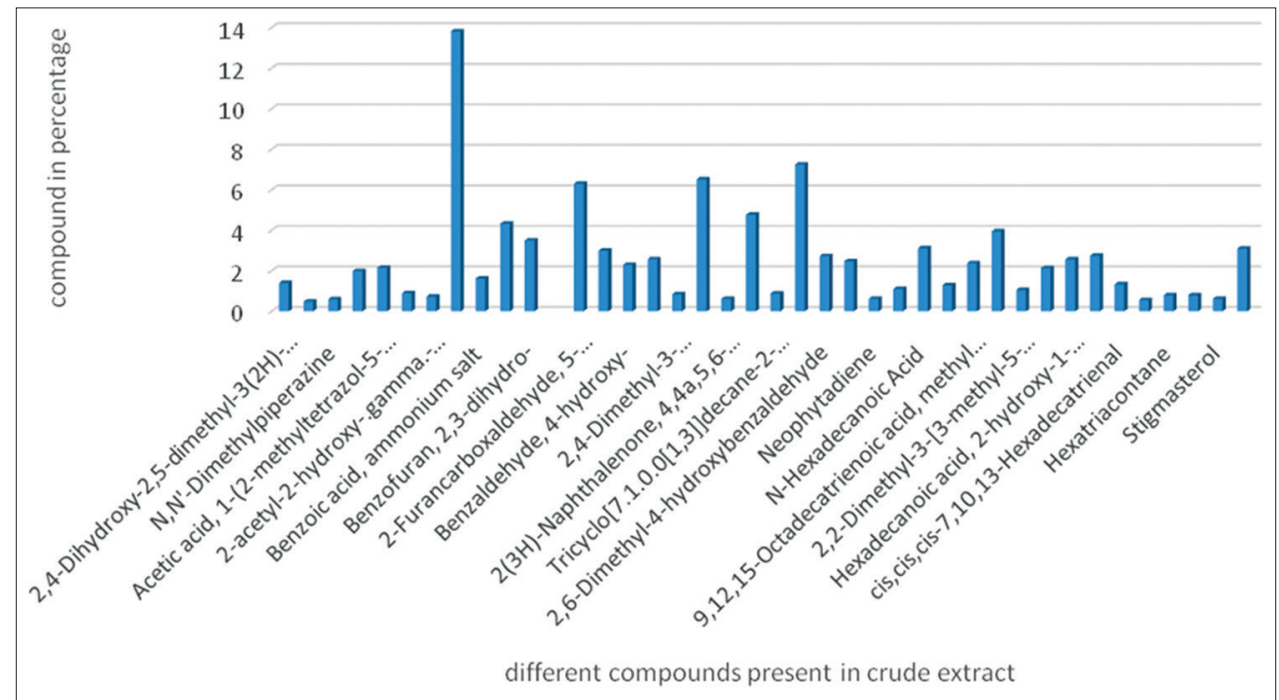

Fig. 7: Gas chromatography and mass spectroscopy of crude Pavetta crassicaulis Bremek. ethanolic flower extract showing percentage of different compounds

that petroleum ether and chloroform extract did not showed any anti-inflammatory activity against carrageenin-induced rat hind paw edema in all concentrations compared with the control. Leaf ethanolic extract showed appreciable anti-inflammatory in all the concentrations $(100,150,200,250$, and $500 \mathrm{mg} / \mathrm{kg}$ concentration) by ANOVA statistical analysis obtained values were validated, which revealed that the leaf ethanolic extract of $P$. crassicaulis Bremek. was highly significant against carrageenin-induced rat hind paw edema in all concentrations in all the interval time. The leaf ethanolic extract of $P$. crassicaulis Bremek. excellent in reducing edema induced by carrageenan in all the phases. Therefore, leaf ethanolic extract of $P$. crassicaulis Bremek. crude extract definitely possess anti- 
Table 3: Presence of metabolites in GC-MS analysis of crude ethanolic extract of $P$. crassicaulis Bremek. flower collected from Western Ghats Karnataka

\begin{tabular}{|c|c|c|c|}
\hline Sl. No & Chemical compound present & Average percentage & Properties of the compound \\
\hline 1 & 2,4-dihydroxy-2,5-dimethyl-3 (2H)-furan-3-one & 1.40 & Food-grade flavor ingredients [30] \\
\hline 2 & 1-butanamine, 2-methyl-N-(2-methylbutylidene)- & 0.48 & Unknown \\
\hline 3 & N, N'-Dimethylpiperazine & 0.60 & $\begin{array}{l}\text { Anthelmintics, antiallergenic, antibacterial, } \\
\text { antihistamic, antiemetic and antimigraine } \\
\text { agents, insecticides, accelerators for rubber, } \\
\text { urethane catalysts, and antioxidants [55] }\end{array}$ \\
\hline 4 & 2,5-dimethyl-4-hydroxy-3 (2H)-furanone & 1.99 & Food-grade flavor ingredients [31] \\
\hline 5 & Acetic acid, 1-(2-methyltetrazol-5-yl) ethenyl ester & 2.15 & $\begin{array}{l}\text { Antiarrhythmia agents, antifungal agents, } \\
\text { carminative, antispasmodic, flavoring agents, } \\
\text { adhesives, paint additives [56] }\end{array}$ \\
\hline 6 & Butanedioic acid, monomethyl ester & 0.90 & $\begin{array}{l}\text { Beverage industry, primarily as an acidity } \\
\text { regulator [57] }\end{array}$ \\
\hline 7 & 2-acetyl-2-hydroxy-.gamma.-butyrolactone & 0.73 & Unknown \\
\hline 8 & 4H-pyran-4-one, 2,3-dihydro-3,5-dihydroxy-6-methyl- & 13.82 & $\begin{array}{l}\text { Mutagen antimicrobial, anti-inflammatory and } \\
\text { antioxidant capacity [27-29] }\end{array}$ \\
\hline 9 & Benzoic acid, ammonium salt & 1.62 & $\begin{array}{l}\text { Industrial preservative for paper wrappers, } \\
\text { agent for reducing curing time in vulcanization } \\
\text { of rubber, expectorant used for chronic } \\
\text { bronchitis, analytical reagent for various } \\
\text { elements, urinary anti-infective [58] }\end{array}$ \\
\hline 10 & 1,2-Benzenediol & 4.33 & $\begin{array}{l}\text { Flavoring agents, pharmaceuticals and } \\
\text { cosmetics, antioxidant, antibacterial }[59,60]\end{array}$ \\
\hline 11 & Benzofuran, 2,3-dihydro- & 3.50 & Toxic [61] \\
\hline 12 & 2-Furancarboxaldehyde, 5-(hydroxymethyl)- & 6.30 & Food industry as flavoring agent [62] \\
\hline 13 & 1,2,3-Propanetriol, diacetate & 3.00 & $\begin{array}{l}\text { As a sweetener; in the manufacture of } \\
\text { dynamite, cosmetics, liquid soaps, candy, } \\
\text { liqueurs, inks, and lubricants; to keep fabrics } \\
\text { pliable; as a component of antifreeze mixtures; } \\
\text { as a source of nutrients for fermentation } \\
\text { cultures in the production of antibiotics and in } \\
\text { medicine [63] }\end{array}$ \\
\hline 14 & Benzaldehyde, 4-hydroxy- & 2.30 & Flavor and fragrance agents [37] \\
\hline 15 & 2-Methoxy-4-vinylphenol & 2.58 & $\begin{array}{l}\text { Flavoring agent, antibacterial activity, } \\
\text { anti-inflammatory effect }[38,39,64]\end{array}$ \\
\hline 16 & 2,4-Dimethyl-3-nitrobicyclo[3.2.1]octan-8-one & 0.85 & $\begin{array}{l}\text { Oils obtained from myrrh and frankincense and } \\
\text { parthenium weed have little percentage }[42,43]\end{array}$ \\
\hline 17 & Benzaldehyde, 2-hydroxy-6-methyl- & 6.52 & $\begin{array}{l}\text { Pheromone of the acarid mite Tyrophagus } \\
\text { perniciosus and grain mite Aleuroglyphus } \\
\text { ovatus }[44,45]\end{array}$ \\
\hline 18 & 2 (3H)-naphthalenone, 4,4a, 5,6-tetrahydro- & 0.62 & Unknown \\
\hline 19 & Methyl Ester Of Bicyclo[4.3.0] & 4.77 & Unknown \\
\hline 20 & $\begin{array}{l}\text { Non-1 (b)-En-4, /-Dione-8-Larboxylic Acld } \\
\text { Tricyclo[7.1.0.0[1,3]]decane-2-carbaldehyde }\end{array}$ & 0.88 & Unknown \\
\hline 21 & Benzaldehyde, 2-methyl- & 7.25 & Perfumes, flavoring agents [65] \\
\hline 22 & 2,6-dimethyl-4-hydroxybenzaldehyde & 2.73 & $\begin{array}{l}\text { Causes skin irritation, serious eye irritation, } \\
\text { respiratory irritation, herbicides, neuropathic } \\
\text { pain [66] }\end{array}$ \\
\hline 23 & 4-((1E)-3-Hydroxy-1-propenyl)-2-methoxyphenol & 2.47 & $\begin{array}{l}\text { Antimicrobial, antioxidant, anti-inflammatory, } \\
\text { analgesic [34] }\end{array}$ \\
\hline 24 & Neophytadiene & 0.62 & $\begin{array}{l}\text { As additive for liquid cigarette can improve } \\
\text { aroma and evaporation rate [67] }\end{array}$ \\
\hline 25 & Hexadecanoic acid, methyl ester & 1.11 & $\begin{array}{l}\text { Antioxidant, hypocholesterolemic, nematicide, } \\
\text { pesticide, anti-androgenic flavor, hemolytic, } \\
\text { 5-alpha reductase inhibitor, surface active } \\
\text { agents, laundry, and dishwashing products [52] }\end{array}$ \\
\hline 26 & N-hexadecanoic acid & 3.11 & $\begin{array}{l}\text { Anti-inflammatory, psychotropic drug, } \\
\text { anti-oxidant, hypocholesterolemic, nematicide, } \\
\text { pesticide, lubricant, antiandrogenic, flavor, } \\
\text { hemolytic 5-alpha reductase inhibitor [68] }\end{array}$ \\
\hline 27 & 9,12-octadecadienoic acid, methyl ester & 1.29 & $\begin{array}{l}\text { Anti-inflammatory, nematicide, insectifuge, } \\
\text { hypocholesterolemic, cancer preventive, } \\
\text { hepatoprotective, antihistaminic, anti-acne, } \\
\text { anti-arthritic, anti-eczemic, } 5 \text {-alpha reductase } \\
\text { inhibitor, antiandrogenic, anticoronary }[68,69]\end{array}$ \\
\hline
\end{tabular}


Table 3: (Continued)

\begin{tabular}{|c|c|c|c|}
\hline Sl. No & Chemical compound present & Average percentage & Properties of the compound \\
\hline 28 & 9,12,15-octadecatrienoic acid, methyl ester, (Z, Z, Z)- & 2.38 & $\begin{array}{l}\text { Anti-inflammatory, insectifuge } \\
\text { hypocholesterolemic, cancer preventive, } \\
\text { nematicide, hepatoprotective, insectifuge, } \\
\text { anti-histaminic, anti-eczemic, anti-acne, } \\
\text { 5-alpha reductase inhibitor, anti-androgenic, } \\
\text { anti-arthritic, anti-coronary [68] }\end{array}$ \\
\hline 29 & $\begin{array}{l}\text { Alpha.-D-glucopyranose, 4-0-. } \\
\text { beta.-D-galactopyranosyl- }\end{array}$ & 3.95 & $\begin{array}{l}\text { Indicator carbohydrate for intestinal } \\
\text { permeability in Crohn's disease and } \\
\text { malabsorption syndrome [70] }\end{array}$ \\
\hline 30 & $\begin{array}{l}\text { 2,2-Dimethyl-3-[3-methyl-5-(phenylthio) pent-3-enyl] } \\
\text { oxirane }\end{array}$ & 1.06 & Unknown \\
\hline 31 & Benzoyl .beta.-d-glucoside & 2.13 & Unknown \\
\hline 32 & $\begin{array}{l}\text { Hexadecanoic acid, 2-hydroxy-1-(hydroxymethyl) } \\
\text { ethyl ester }\end{array}$ & 2.57 & $\begin{array}{l}\text { Wound healing activity, hemolytic, pesticide, } \\
\text { flavor, antioxidant [51] }\end{array}$ \\
\hline 33 & $\begin{array}{l}\text { 9,12-octadecadienoic acid (Z, Z)-, } \\
\text { 2-hydroxy-1-(hydroxymethyl) ethyl ester }\end{array}$ & 2.75 & $\begin{array}{l}\text { Component of cigarette smoke, } \\
\text { hypocholesterolemic, nematicide, anti-arthritic, } \\
\text { hepatoprotective, antiandrogenic, } \\
\text { hypocholesterolemic } 5 \text {-alpha reductase } \\
\text { inhibitor, antihistaminic, anticoronary, } \\
\text { insectifuge, anti-eczemic, anti-acne [53] }\end{array}$ \\
\hline 34 & cis, cis, cis-7,10,13-hexadecatrienal & 1.34 & Unknown \\
\hline 35 & $\begin{array}{l}\text { 2,6,10,14,18,22-tetracosahexaene, } \\
\text { 2,6,10,15,19,23-hexamethyl- }\end{array}$ & 0.56 & $\begin{array}{l}\text { Bactericide, antifungal, cytotoxic, antibacterial, } \\
\text { antioxidant, antitumor, cancer preventive, } \\
\text { immunostimulant, chemopreventive, } \\
\text { lipoxygenase-inhibitor, perfumery, pesticide, } \\
\text { and sunscreen [53] }\end{array}$ \\
\hline 36 & Hexatriacontane & 0.80 & $\begin{array}{l}\text { Drug delivery mediums for topical and } \\
\text { oral pharmaceuticals, organic application } \\
\text { mediums for cosmetics, cleaning materials } \\
\text { for art conservation, as delivery mediums } \\
\text { and/or nutrients in nutraceuticals (vitamins } \\
\text { and supplements), particles in personal } \\
\text { care products (shampoo, conditioner, soap, } \\
\text { toothpaste, etc., an crystalline fat alternative in } \\
\text { food processing [71] }\end{array}$ \\
\hline 37 & Campesterol & 0.80 & $\begin{array}{l}\text { Campesterol is also sometimes used to treat } \\
\text { some specific prostate conditions, used in } \\
\text { nutrient medicines such as nutrients, body } \\
\text { building supplements, and food additive [72] }\end{array}$ \\
\hline 38 & Stigmasterol & 0.62 & $\begin{array}{l}\text { Antimicrobial, anticancer, anti-arthritic, } \\
\text { antiasthma, diuretic, anti-inflammatory [53] }\end{array}$ \\
\hline 39 & $\beta$.-Sitosterol & 3.10 & $\begin{array}{l}\text { Anabolic steroids in sports, heart disease, and } \\
\text { high cholesterol. It is also used for boosting } \\
\text { the immune system and for preventing } \\
\text { colon cancer, as well as for gallstones, the } \\
\text { common cold and flu (influenza), HIV/AIDS, } \\
\text { rheumatoid arthritis, tuberculosis, psoriasis, } \\
\text { allergies, cervical cancer, fibromyalgia, } \\
\text { systemic lupus erythematosus, asthma, hair } \\
\text { loss, bronchitis, migraine headache, and } \\
\text { chronic fatigue syndrome, anti-inflammatory, } \\
\text { anti-cancer, antidiabetic, antipyretic, and } \\
\text { antioxidant [73-79] }\end{array}$ \\
\hline
\end{tabular}

GC-MS: Gas chromatography and mass spectroscopy, P. crassicaulis: Pavetta crassicaulis

inflammatory secondary metabolites which was reducing the paw edema significantly (Table 4 , Figs. 16 and 17).

\section{Anti-inflammatory activity of flower crude extracts}

Like leaf ethnolic extract, the flower ethanolic extract also showed appreciated effect in suppressing inflammation. Here, also petroleum ether and chloroform showed nil effect on the tested animals in suppressing inflammation. The activity is dose dependent and in all the concentrations $(100,150,200,250$, and $500 \mathrm{mg} / \mathrm{kg}$ concentration), the ethanolic flower extract showed excellent activity which is revealed statistically through one-way ANOVA. By this, it is proved that ethanolic leaves extract having some metabolite responsible for its antiinflammatory activity (Table 5 , Figs. 18 and 19).

\section{Percentage of inflammation inhibition of all leaf extracts}

The percentage of inflammation inhibition of the petroleum ether and chloroform leaf crude extracts were initially showed negative values $(0-1 \mathrm{~h})$ after the initial hours $(2-4 \mathrm{~h})$, these extracts also showed positive results with little inflammation inhibition at final hour $(6 \mathrm{~h})$. The ethanolic crude extract showed excellent results in all the time intervals, in all the concentrations $(100,150,200,250$, and $500 \mathrm{mg} / \mathrm{kg})$. In all the crude extracts, ethanolic extract has excellent inflammation 


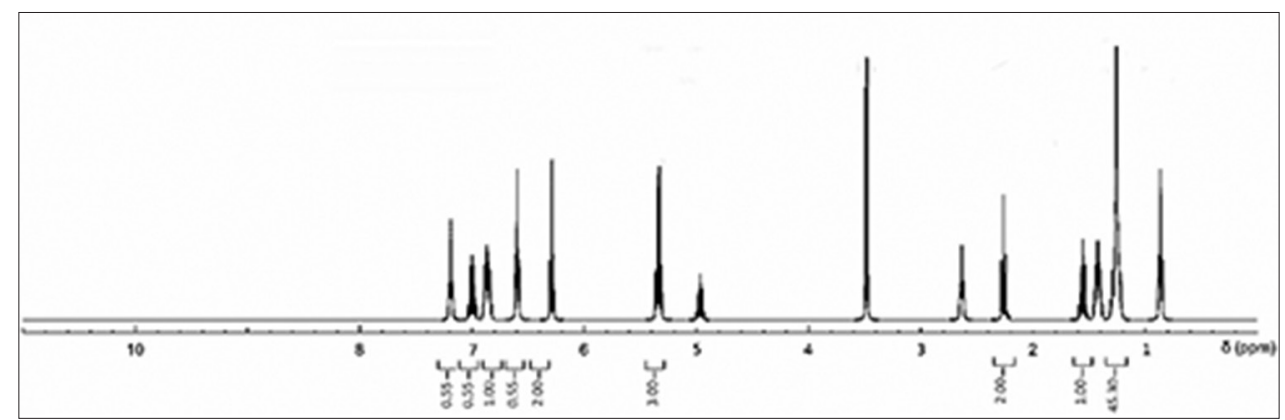

Fig. 8: 2-tert-butyl-4,6-bis(3,5-di-tert-butyl-4-hydroxybenzyl)phenol- ${ }^{1} \mathrm{H}$ NMR spectrum

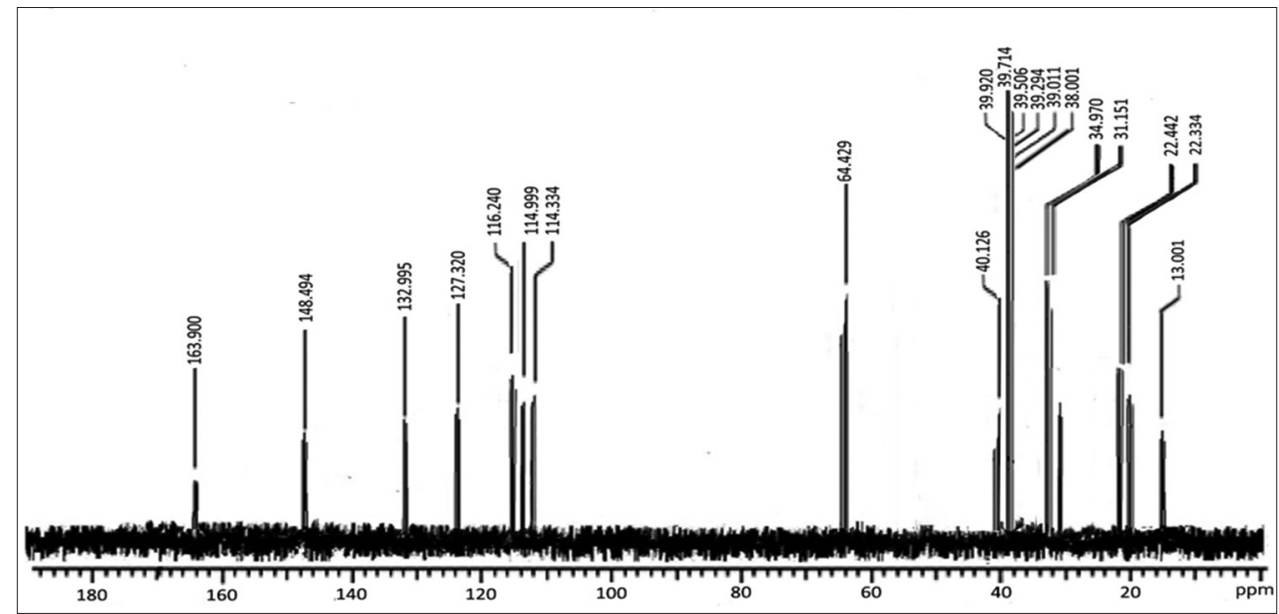

Fig. 9: 2-tert-butyl-4,6-bis(3,5-di-tert-butyl-4-hydroxybenzyl)phenol - ${ }^{13} \mathrm{C}$ NMR spectrum

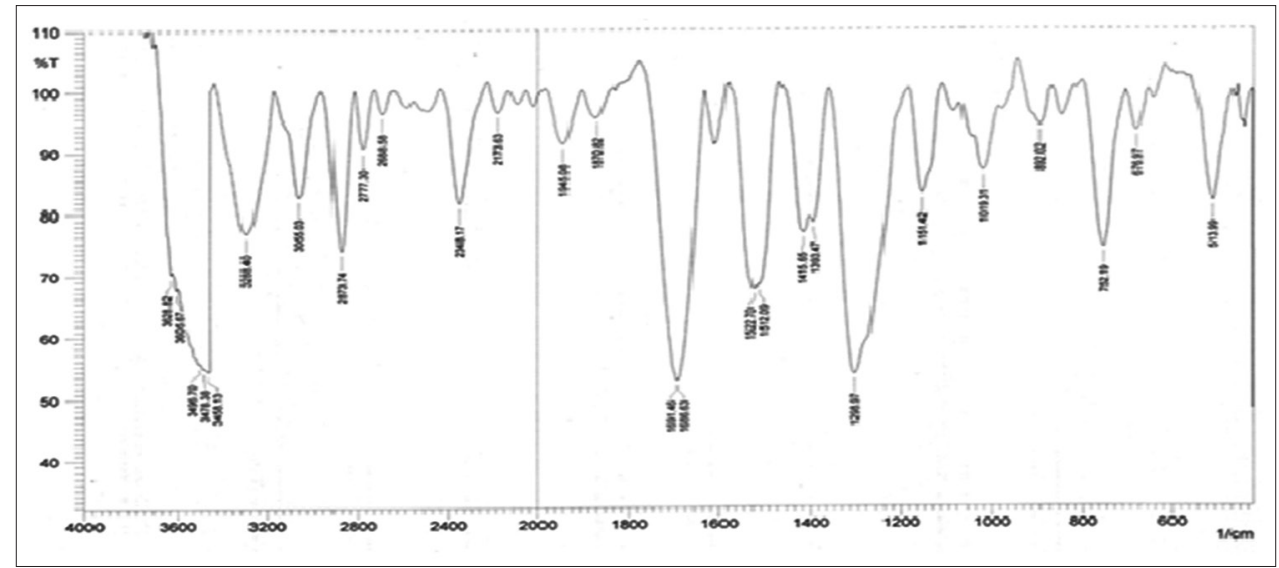

Fig. 10: 2-tert-butyl-4,6-bis(3,5-di-tert-butyl-4-hydroxybenzyl)phenol - infrared spectrum

suppression activity and rest of the extracts has negligible inflammation suppression (Table 6, Figs. 20 and 21)

Percentage of inflammation inhibition of all flower extracts For initial hours, petroleum ether and chloroform flower extracts were showed negative values $(0-1 \mathrm{~h})$ after that $(2-4 \mathrm{~h})$ petroleum ether and chloroform extracts also showed positive results with little inflammation inhibition. The flower ethanolic extract showed appreciable inflammation suppression activity in all the time intervals, in all the concentrations $(100,150,200,250$, and $500 \mathrm{mg} / \mathrm{kg}$ ) (Table 7, Figs. 22 and 23).
Anti-inflammatory activity of pure compound 2-tert-butyl-4,6bis(3,5-di-tert-butyl-4-hydroxybenzyl)phenol

The pure compound "2-tert-butyl-4,6-bis(3,5-di-tert-butyl-4hydroxybenzyl)phenol" (10 $\mathrm{mg} / \mathrm{kg}$ ) which is extracted from ethanolic leaf crude extract of $P$. crassicaulis Bremek. has excellent anti-inflammatory activity which is almost equal to the standard diclofenac $(10 \mathrm{mg} / \mathrm{kg})$ used in all the intervals of time. By statistical tool ANOVA, it is revealed that the activity showed by the pure compound which is equivalent to the standard used(Table 4 and Figs. 17, 20, 21). 


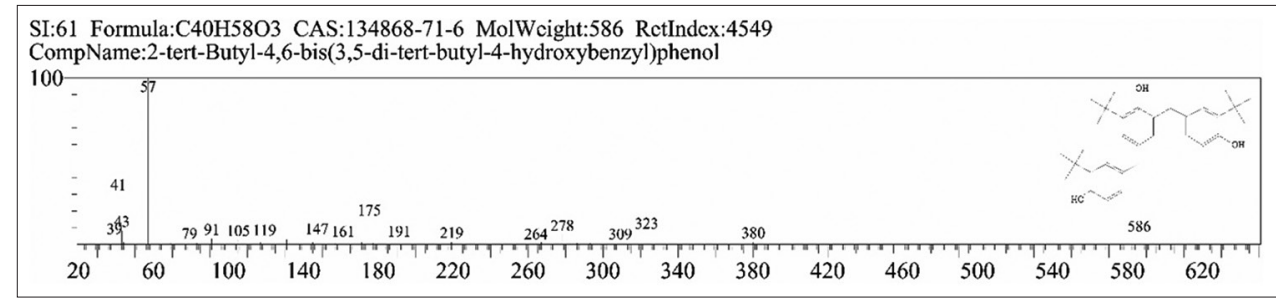

Fig. 11: 2-tert-butyl-4,6-bis(3,5-di-tert-butyl-4-hydroxybenzyl)phenol - mass spectrum

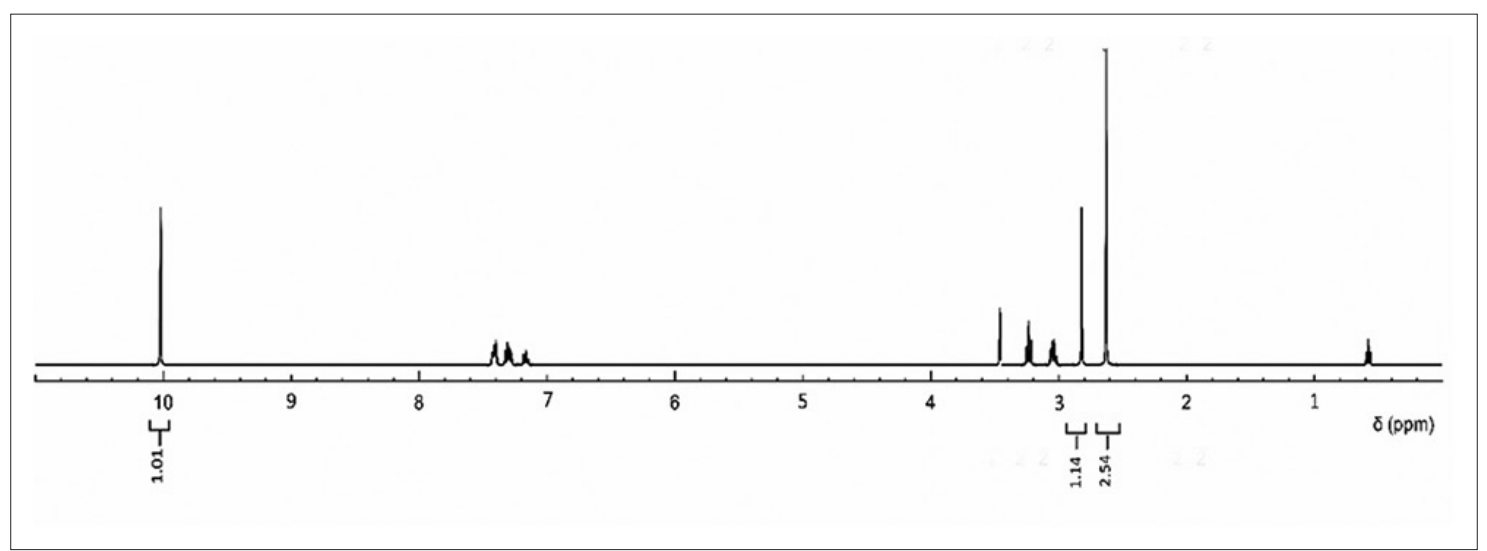

Fig. 12: 4H-pyran-4-one,2,3-dihydro-3,5-dihydroxy-6-methyl- ${ }^{1} \mathrm{HNMR}$ spectrum

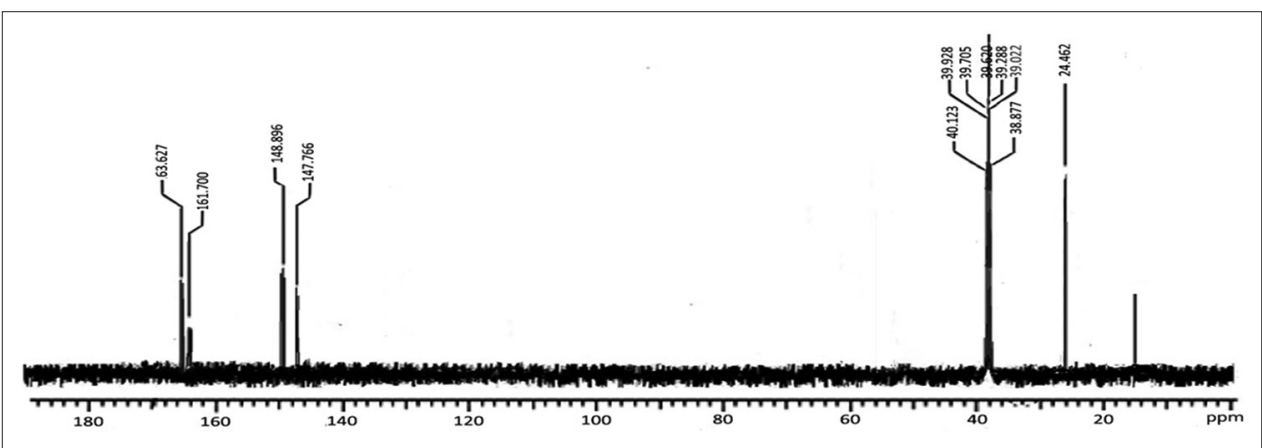

Fig. 13: 4H-pyran-4-one,2,3-dihydro-3,5-dihydroxy-6-methyl- ${ }^{13} \mathrm{C}$ NMR spectrum

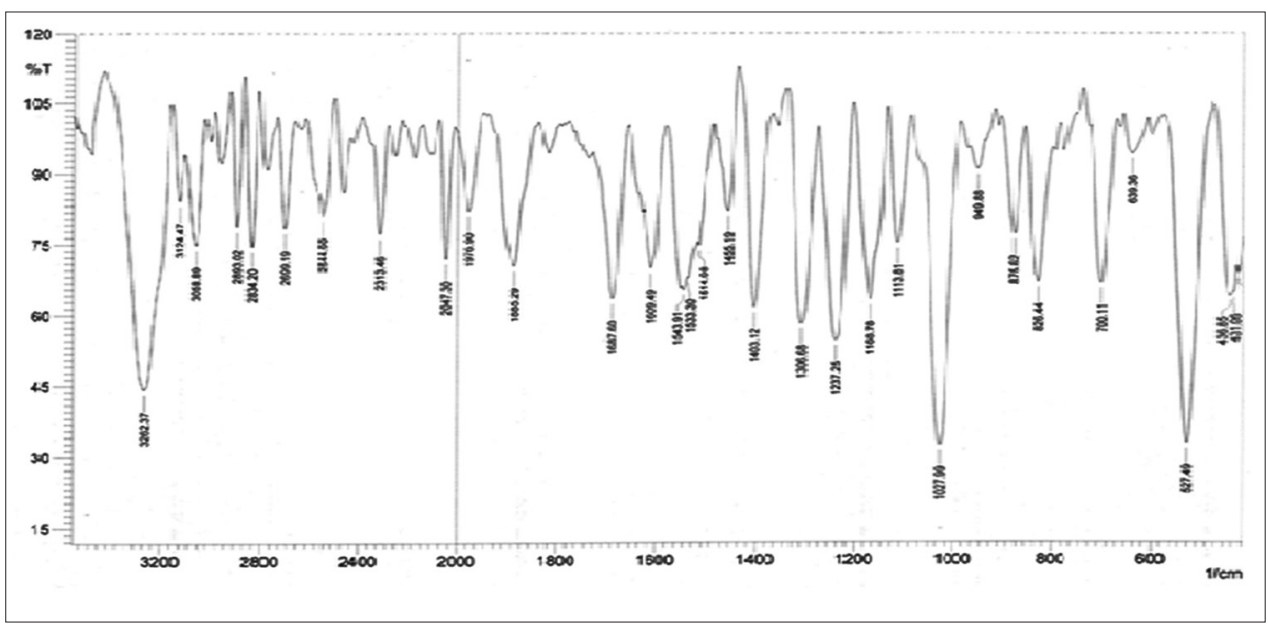

Fig. 14: 4H-pyran-4-one,2,3-dihydro-3,5-dihydroxy-6-methyl- infrared spectrum 


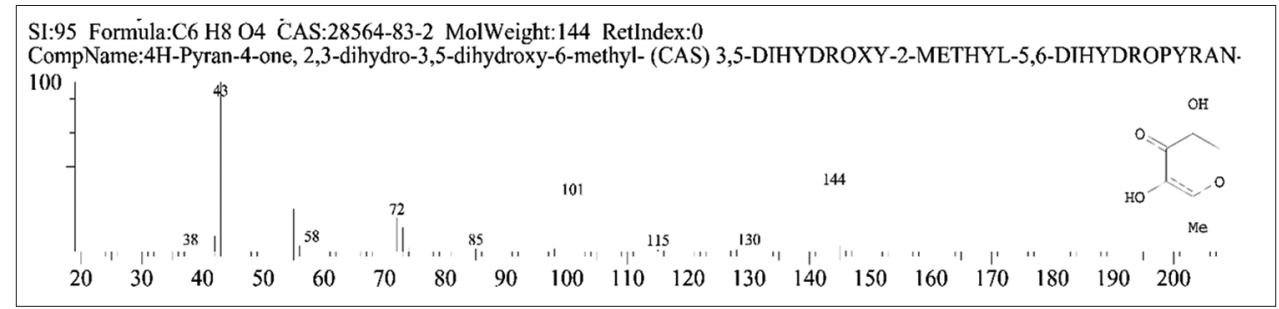

Fig. 15: 4H-pyran-4-one,2,3-dihydro-3,5-dihydroxy-6-methyl- mass spectrum

Table 4: Anti-inflammatory activity of different solvent extracts of $P$. crassicaulis Bremek. leaf and its pure compound at different time intervals

\begin{tabular}{|c|c|c|c|c|c|c|}
\hline \multirow{2}{*}{$\begin{array}{l}\text { Extracts/pure compound/standard } \\
\text { drug/control }\end{array}$} & \multirow[t]{2}{*}{ Dose mg/kg } & \multicolumn{5}{|c|}{ Time in hours/paw volume (ml) } \\
\hline & & $\mathbf{O} \mathbf{h}$ & $1 \mathrm{~h}$ & $2 \mathrm{~h}$ & $4 \mathrm{~h}$ & $6 \mathrm{~h}$ \\
\hline \multirow[t]{5}{*}{ Petroleum ether } & 100 & $2.95 \pm 0.05$ & $2.64 \pm 0.01$ & $2.5 \pm 0.07$ & $2.38 \pm 0.01$ & $2.37 \pm 0.01$ \\
\hline & 150 & $2.86 \pm 0.03$ & $2.59 \pm 0.07$ & $2.47 \pm 0.01$ & $2.25 \pm 0.04$ & $2.23 \pm 0.04$ \\
\hline & 200 & $2.78 \pm 0.02$ & $2.55 \pm 0.05$ & $2.43 \pm 0.04$ & $2.17 \pm 0.01$ & $2.17 \pm 0.01$ \\
\hline & 250 & $2.75 \pm 0.05$ & $2.48 \pm 0.06$ & $2.4 \pm 0$ & $2.03 \pm 0.02$ & $2.06 \pm 0.01$ \\
\hline & 500 & $2.71 \pm 0.04$ & $2.38 \pm 0.06$ & $2.38 \pm 0.01$ & $1.98 \pm 0$ & $1.95 \pm 0.04$ \\
\hline \multirow{4}{*}{ Chloroform } & 150 & $2.74 \pm 0.05$ & $2.46 \pm 0.09$ & $2.47 \pm 0.01$ & $2.46 \pm 0$ & $2.46 \pm 0$ \\
\hline & 200 & $2.62 \pm 0.01$ & $2.44 \pm 0.04$ & $2.43 \pm 0.02$ & $2.44 \pm 0.04$ & $2.42 \pm 0.05$ \\
\hline & 250 & $2.58 \pm 0.05$ & $2.42 \pm 0.01$ & $2.4 \pm 0.03$ & $2.42 \pm 0.01$ & $2.34 \pm 0.02$ \\
\hline & 500 & $2.49 \pm 0.09$ & $2.33 \pm 0.04$ & $2.38 \pm 0$ & $2.4 \pm 0.02$ & $2.3 \pm 0.09$ \\
\hline \multirow[t]{4}{*}{ Ethanolic extract } & 100 & $1.11 \pm 0.08^{* * *}$ & $1.49 \pm 0.09^{* * *}$ & $1.23 \pm 0.01^{* * *}$ & $1.13 \pm 0.01^{* * *}$ & $1.12 \pm 0.03^{* * *}$ \\
\hline & 150 & $0.85 \pm 0.03^{* * *}$ & $1.06 \pm 0.04^{* * *}$ & $1.02 \pm 0.05^{* * *}$ & $0.99 \pm 0.01^{* * *}$ & $1.07 \pm 0.02^{* * *}$ \\
\hline & 200 & $0.71 \pm 0.03^{* * *}$ & $0.95 \pm 0.05^{* * *}$ & $0.97 \pm 0.01^{* * *}$ & $0.83 \pm 0.03^{* * *}$ & $0.92 \pm 0.05^{* * *}$ \\
\hline & 500 & $0.5 \pm 0.09 * * *$ & $0.71 \pm 0.08^{* * *}$ & $0.75 \pm 0.04^{* * *}$ & $0.62 \pm 0.02 * * *$ & $0.72 \pm 0.02^{* * *}$ \\
\hline Standard diclofenac sodium & 10 & $0.46 \pm 0.028^{* * *}$ & $0.65 \pm 0.03^{* * *}$ & $0.62 \pm 0.03^{* * *}$ & $0.65 \pm 0.03^{* * *}$ & $0.55 \pm 0.03^{* * *}$ \\
\hline 2-tert-butyl-4,6-bis & 10 & $0.39 \pm 0.005^{* * *}$ & $0.67 \pm 0.02^{* * *}$ & $0.67 \pm 0.02^{* * *}$ & $0.67 \pm 0.02^{* * *}$ & $0.59 \pm 0 * * *$ \\
\hline (3,5-di-tert- butyl-4-hydroxybenzyl) phenol & & & & & & \\
\hline Control & - & $2.15 \pm 0.02$ & $2.33 \pm 0.02$ & $2.65 \pm 0.01$ & $2.68 \pm 0.06$ & $2.55 \pm 0.1$ \\
\hline
\end{tabular}

The data are presented as mean \pm SEM, $n=6$. Statistical analysis were performed using one-way analysis of variance (ANOVA), followed by Dunnet's multiple comparison test. Levels of significance: ${ }^{*} \mathrm{p}=0.05,{ }^{* *} \mathrm{p}<0.01, \mathrm{p}<{ }^{* * *} 0.001$ compared to control group. SEM: Standard error of the mean, P. crassicaulis: Pavetta crassicaulis

Table 5: Anti-inflammatory activity of different solvent extracts of $P$. crassicaulis Bremek flower and its pure compound at different time intervals

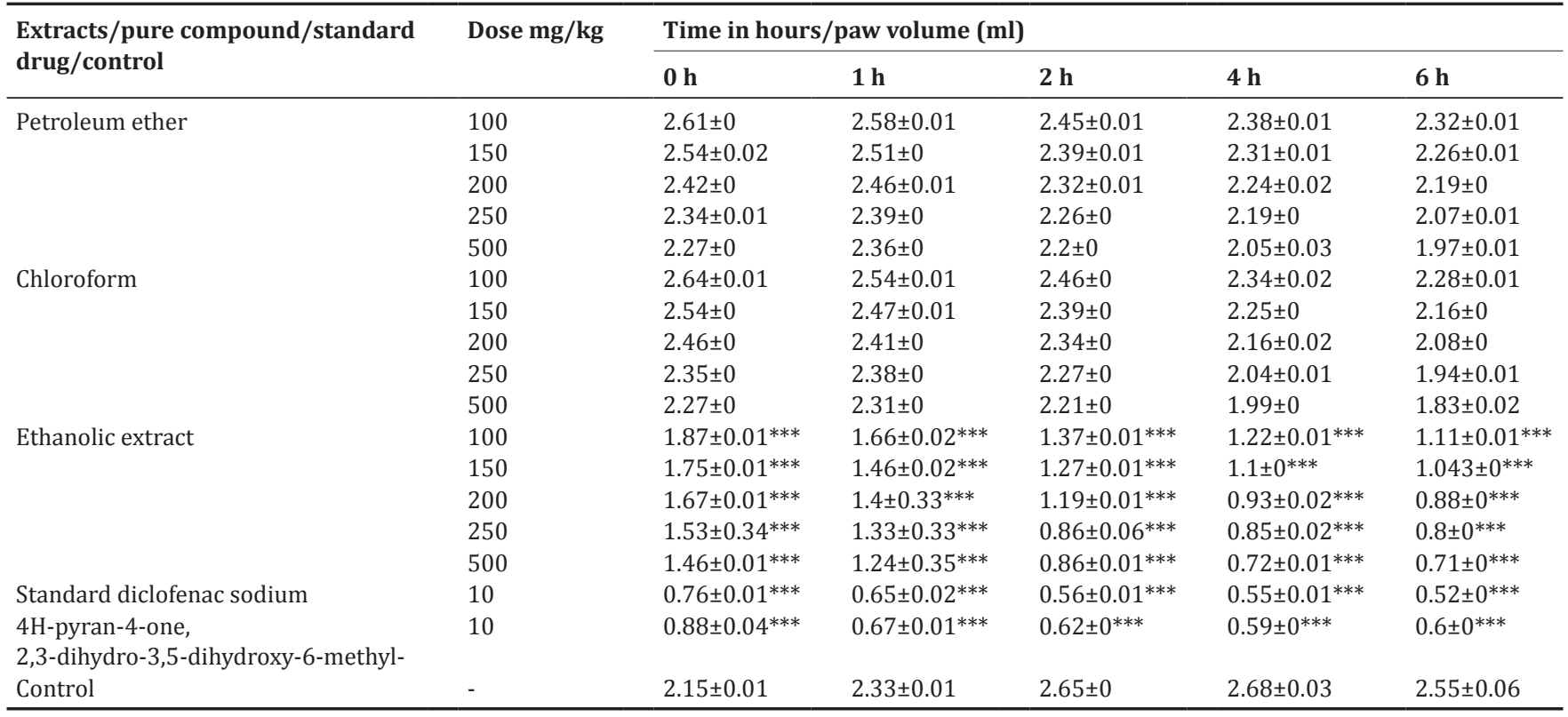

The data are presented as mean \pm SEM, $n=6$. Statistical analysis were performed using one-way analysis of variance (ANOVA), followed by Dunnet's multiple comparison test. Levels of significance: ${ }^{*} \mathrm{p}=0.05,{ }^{* *} \mathrm{p}<0.01,{ }^{* * *} \mathrm{p}<0.001$ compared to control group. SEM: Standard error of the mean, P. crassicaulis: Pavetta crassicaulis 


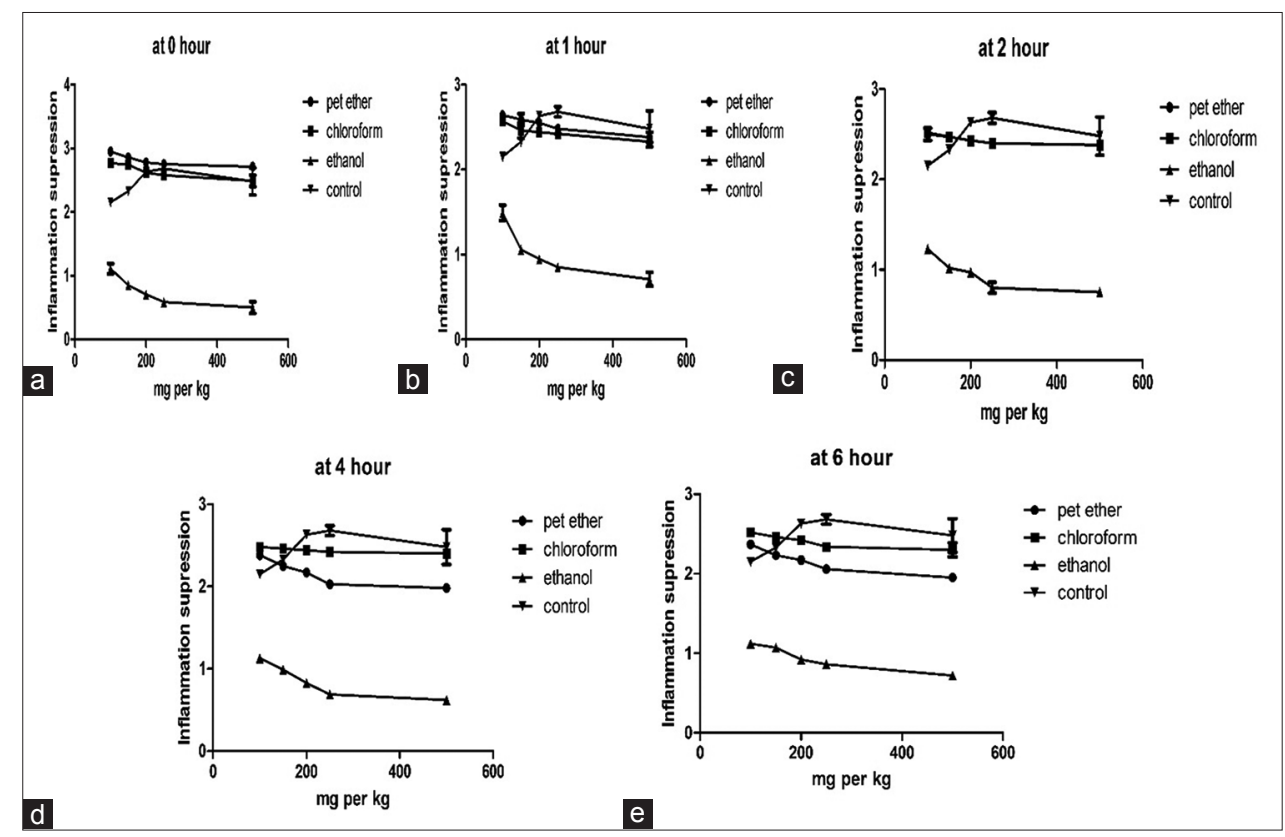

Fig. 16: (a-e) Anti-inflammatory activity of different solvent extracts of Pavetta crassicaulis Bremek. leaf compared with the control at different time intervals

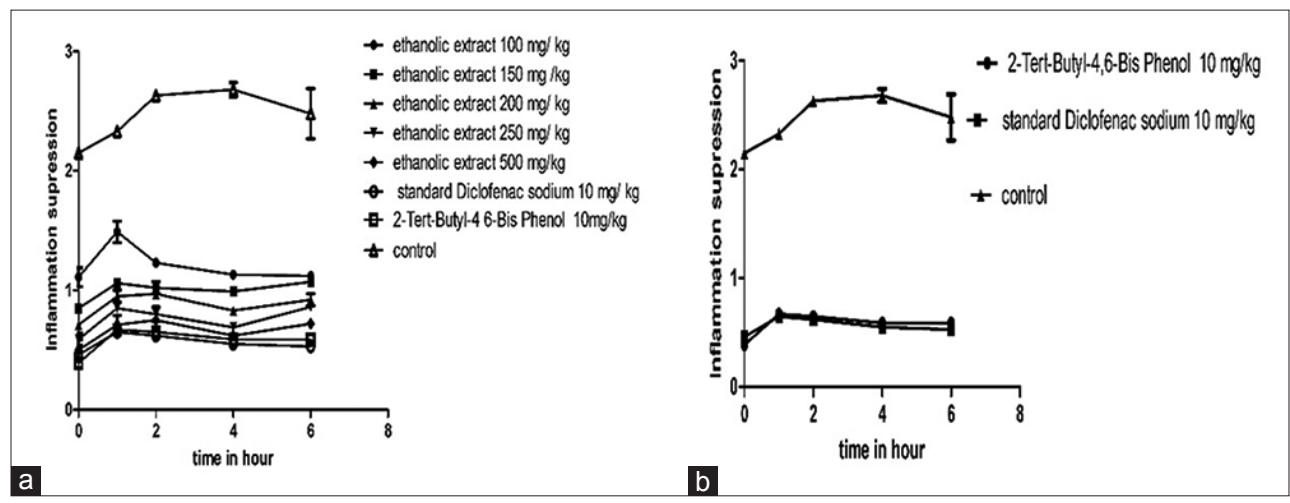

Fig. 17: (a-b) Anti-inflammatory activity of Pavetta crassicaulis Bremek. leaf ethanolic extracts and its pure compound compared with standard and control at different time intervals

Table 6: Percentage of edema inhibition of different solvent extracts of $P$. crassicaulis Bremek. leaf and its pure compound at different time intervals

\begin{tabular}{|c|c|c|c|c|c|c|}
\hline \multirow[t]{2}{*}{ Extracts/pure compound/standard drug/control } & \multirow[t]{2}{*}{ Dose mg/kg } & \multicolumn{5}{|c|}{ Time in hours/percentage of inhibition of paw edema } \\
\hline & & $\mathbf{O} \mathbf{h}$ & $1 \mathrm{~h}$ & $2 \mathrm{~h}$ & $4 h$ & $6 \mathrm{~h}$ \\
\hline \multirow[t]{4}{*}{ Petroleum ether } & 100 & -37.2 & -13.3 & 4.94 & 11.19 & 7.05 \\
\hline & 200 & -29.3 & -9.44 & 7.6 & 19.02 & 14.9 \\
\hline & 250 & -27.9 & -6.43 & 8.74 & 24.25 & 19.21 \\
\hline & 500 & -26.04 & -2.14 & 9.5 & 26.11 & 23.52 \\
\hline \multirow[t]{5}{*}{ Chloroform } & 100 & -28.83 & -10.3 & 4.18 & 7.46 & 1.17 \\
\hline & 150 & -27.44 & -5.57 & 6.08 & 8.2 & 3.52 \\
\hline & 200 & -21.86 & -4.72 & 7.6 & 8.95 & 5.09 \\
\hline & 250 & -20 & -3.86 & 8.74 & 9.7 & 8.23 \\
\hline & 500 & -15.81 & 0 & 9.5 & 10.44 & 9.8 \\
\hline \multirow[t]{5}{*}{ Ethanolic extract } & 100 & 48.37 & 36.05 & 53.23 & 57.83 & 56.07 \\
\hline & 150 & 60.46 & 54.5 & 61.21 & 63.05 & 58.03 \\
\hline & 200 & 66.97 & 59.22 & 63.11 & 69.02 & 63.92 \\
\hline & 250 & 72.55 & 63.51 & 69.58 & 74.25 & 66.27 \\
\hline & 500 & 76.74 & 69.52 & 71.48 & 76.86 & 71.76 \\
\hline 2-tert-butyl-4,6-bis (3,5-di-tert-butyl-4-hydroxybenzyl) phenol & 10 & 81.86 & 71.24 & 74.52 & 75 & 76.86 \\
\hline Control & - & 0 & 0 & 0 & 0 & 0 \\
\hline
\end{tabular}

Percentage of inhibition was calculated [25] with the formula \% inhibition of edema $=(\mathrm{Vc}-\mathrm{Vt}) / \mathrm{Vc} \times 100 . \mathrm{Vt}=\mathrm{mean}$ paw volume of test group. Vc=mean paw volume of control group. P. crassicaulis: Pavetta crassicaulis 


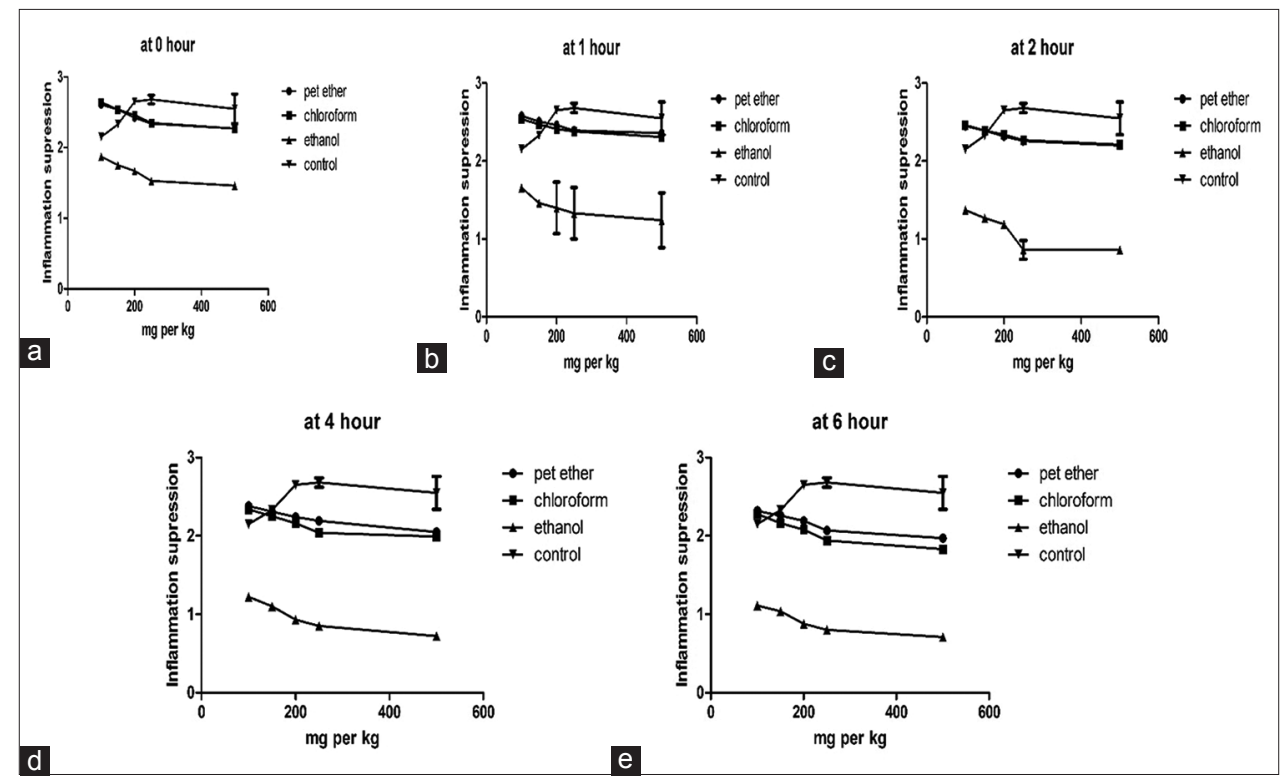

Fig. 18: (a-e) Anti-inflammatory activity of different solvent extracts of Pavetta crassicaulis Bremek. flower compared with the control at different time intervals

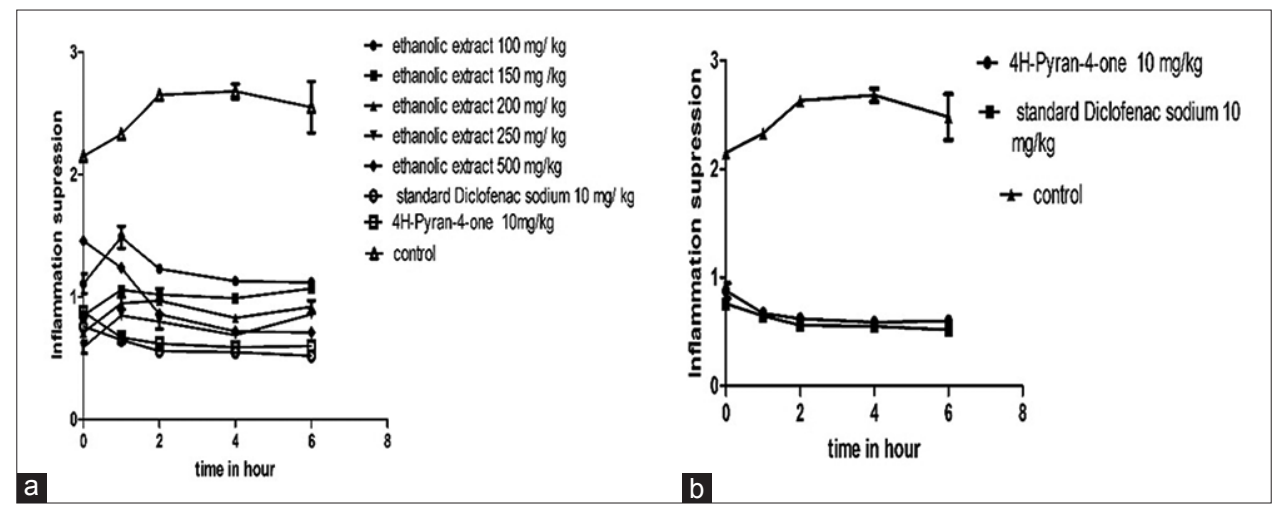

Fig. 19: (a-b) Anti-inflammatory activity of Pavetta crassicaulis Bremek. flower ethanolic extracts and its pure compound compared with standard and control at different time intervals

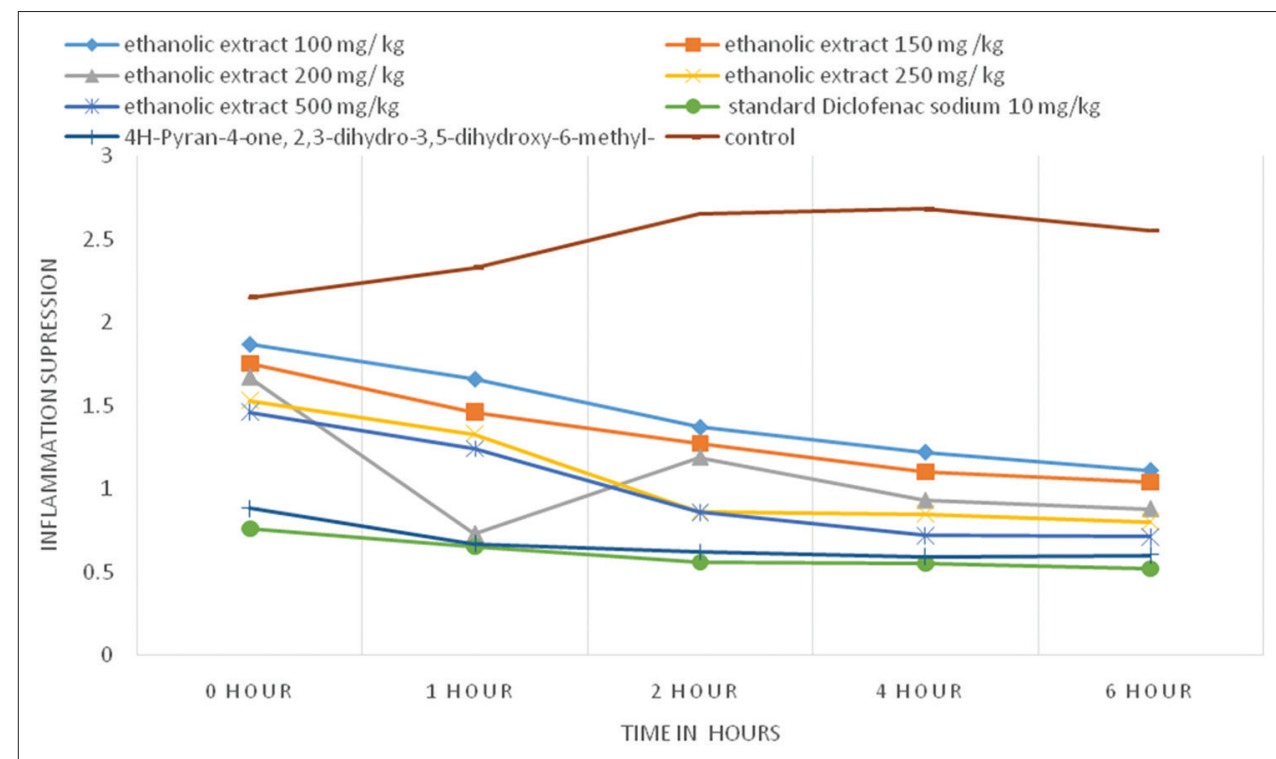

Fig. 20: Inflammation suppression in rats after treating leaf ethanolic extracts and its pure compound at different time intervals at different concentrations 


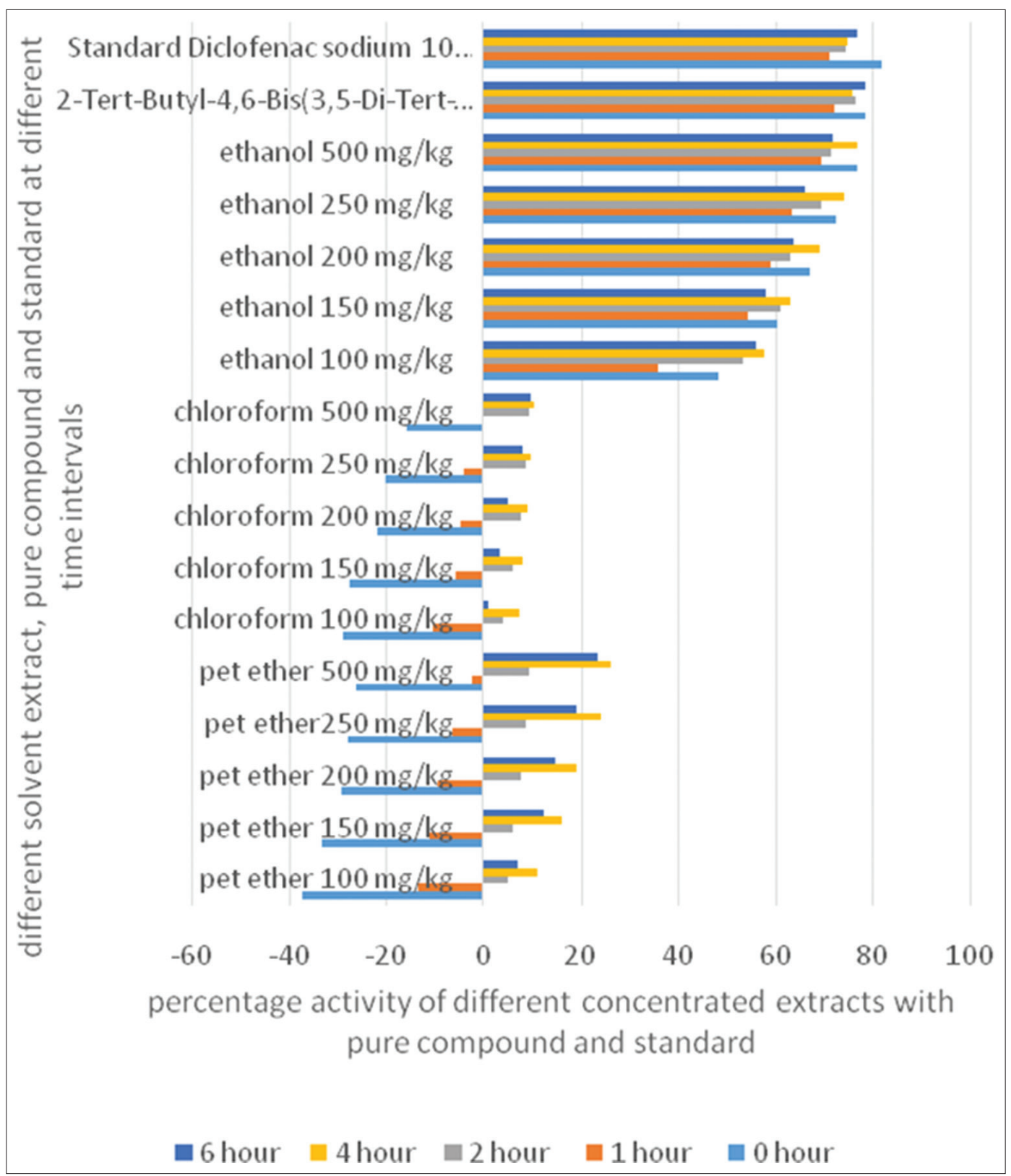

Fig. 21: Percentage inflammation inhibition of different solvent extracts of Pavetta crassicaulis Bremek. leaf at different concentration at different time intervals

Percentage of inflammation inhibition of pure compound 2-tertbutyl-4,6-bis(3,5-di-tert-butyl-4-hydroxybenzyl)phenol

The pure compound 2-tert-butyl-4,6-bis(3,5-di-tert-butyl-4hydroxybenzyl)phenol $(10 \mathrm{mg} / \mathrm{kg})$ has showed excellent percentage of inflammation inhibition almost equal to the standard diclofenac $(10 \mathrm{mg} / \mathrm{kg})$ used in all the intervals of time (Table 6 and Figs. 17, 20, 21).

Anti-inflammatory activity of pure compound 4H-pyran-4one,2,3-dihydro-3,5-dihydroxy-6-methyl-

The pure compound 4H-pyran-4-one,2,3-dihydro-3,5-dihydroxy-6methyl- $(10 \mathrm{mg} / \mathrm{kg})$ which is extracted from ethanolic flower crude extract of $P$. crassicaulis Bremek. has excellent anti-inflammatory activity equal to the standard diclofenac $(10 \mathrm{mg} / \mathrm{kg})$ used in all the intervals of time. By statistical tool ANOVA, it is revealed that the activity showed by the pure compound which is equivalent to the standard used. The results obtained once again withstand the positive activity of the pure compound which was previously tested for its anti-inflammatory activity [27-29] (Table 5 and Figs. 19, 22, 23).
Percentage of inflammation inhibition of pure compound 4H-pyran-4-one, 2,3-dihydro-3,5-dihydroxy-6-methyl-

The pure compound 4H-pyran-4-one,2,3-dihydro-3,5-dihydroxy-6methyl- $(10 \mathrm{mg} / \mathrm{kg})$ has showed excellent percentage of inflammation inhibition which is almost equal to the standard diclofenac $(10 \mathrm{mg} / \mathrm{kg})$ used in all the intervals of time (Table 7 and Figs. 19, 22, 23).

\section{DISCUSSION}

Preliminary quantitative phytochemical analysis of $P$. crassicaulis Bremek. leaf petroleum ether, chloroform crude extracts showed negative results for all the tested phytochemicals aqueous extract gives positive results for saponins and glycosides, but the ethanolic crude extract gives positive confirmation test for saponins, tannins, flavanoids, steroids/sterols, glycosides, and phenols.

Preliminary quantitative phytochemical analysis of $P$. crassicaulis Bremek. flower petroleum ether, chloroform crude extracts showed negative results for all the tested phytochemicals aqueous extract 


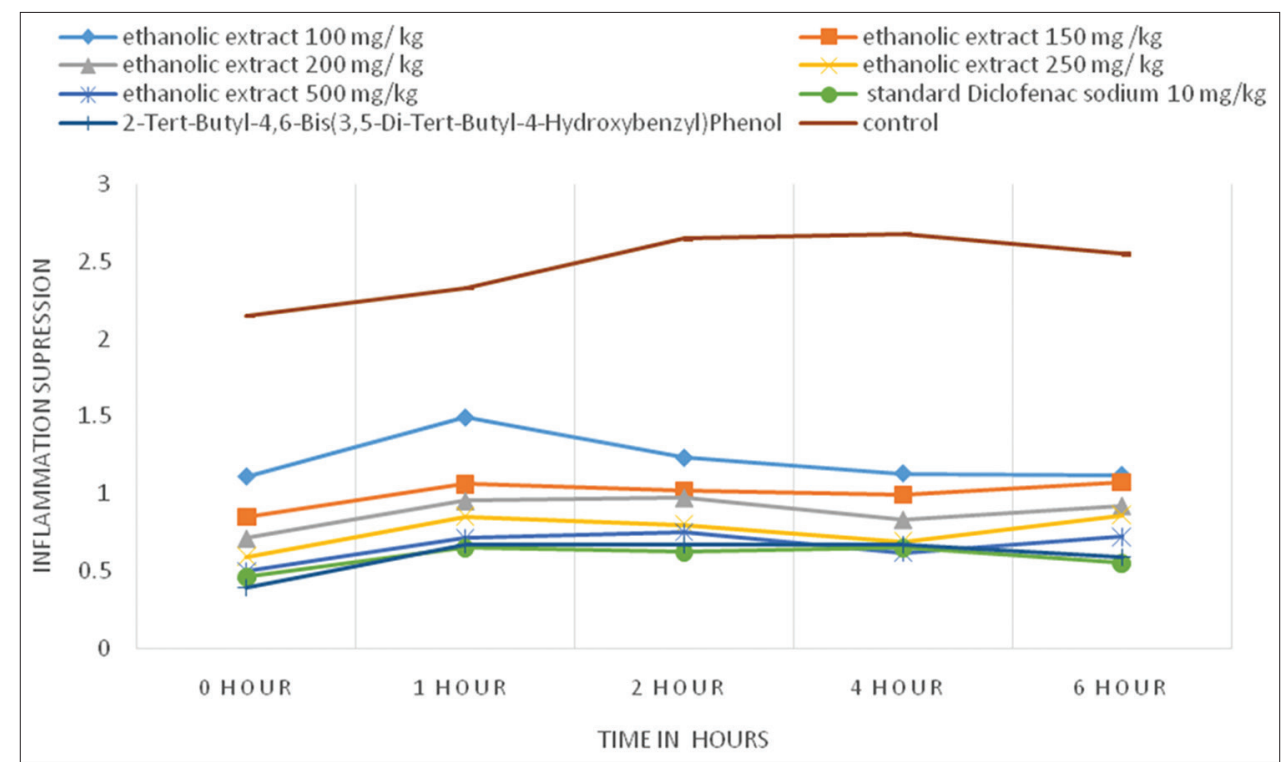

Fig. 22: Inflammation supression in rats after treating flower ethanolic extracts and its pure compound at different time intervals at different concentrations

Table 7: Percentage of edema inhibition of different solvent extracts of $P$. crassicaulis Bremek flower and its pure compound at different time intervals

\begin{tabular}{|c|c|c|c|c|c|c|}
\hline \multirow[t]{2}{*}{ Extracts/pure compound/standard drug/control } & \multirow[t]{2}{*}{ Dose mg/kg } & \multicolumn{5}{|c|}{ Time in hours/percentage of inhibition of paw edema } \\
\hline & & $\mathbf{O} \mathbf{h}$ & $1 \mathrm{~h}$ & $2 \mathrm{~h}$ & $4 \mathrm{~h}$ & $6 \mathrm{~h}$ \\
\hline \multirow[t]{4}{*}{ Petroleum ether } & 100 & -21.39 & -10.72 & 7.54 & 9.01 & 11.19 \\
\hline & 200 & -12.55 & -5.57 & 12.45 & 14.11 & 16.41 \\
\hline & 250 & -8.83 & -2.57 & 14.71 & 18.82 & 18.28 \\
\hline & 500 & -5.58 & -1.28 & 16.98 & 22.74 & 23.5 \\
\hline \multirow[t]{4}{*}{ Chloroform } & 100 & -22.79 & -9.01 & 7.16 & 10.58 & 12.68 \\
\hline & 200 & -14.41 & -3.43 & 11.69 & 18.43 & 19.4 \\
\hline & 250 & -9.3 & -2.14 & 14.33 & 23.92 & 23.88 \\
\hline & 500 & -5.58 & 0.85 & 16.6 & 28.23 & 25.74 \\
\hline \multirow[t]{5}{*}{ Ethanolic extract } & 100 & 13.02 & 28.75 & 48.3 & 56.47 & 54.47 \\
\hline & 150 & 18.6 & 37.33 & 52.07 & 59.21 & 58.95 \\
\hline & 200 & 22.32 & 68.66 & 55.09 & 65.49 & 65.29 \\
\hline & 250 & 28.83 & 42.91 & 67.54 & 68.62 & 68.28 \\
\hline & 500 & 32.09 & 46.78 & 67.54 & 72.15 & 73.13 \\
\hline 4H-pyran-4-one, 2,3-dihydro-3,5-dihydroxy-6-methyl- & 10 & 59.06 & 71.24 & 76.6 & 76.47 & 77.98 \\
\hline Control & - & 0 & 0 & 0 & 0 & 0 \\
\hline
\end{tabular}

Percentage of inhibition was calculated [25] with the formula $\%$ inhibition of edema $=(\mathrm{Vc}-\mathrm{Vt}) / \mathrm{Vc} \times 100$. Vt=mean paw volume of test group. Vc=mean paw volume of control group.

gives positive results for saponins and glycosides, but the ethanolic crude extract gives positive confirmation test for saponins, tannins, flavonoids, steroids/sterols, glycosides, and phenols. This tests confirms that the ethanol dissolves all the phytochemicals from P. crassicaulis Bremek. in a sufficient quantity to influence different phytochemical and pharmacological activities.

Leaf ethanolic crude extract was subjected to GC-MS revealed the presence of 33 compounds (Table 2 and Fig. 2). Among all the confirmed phytochemicals, 21 compounds reported for many medicinal and pharmacological properties and 12 compounds activity was not reported. Among the all the phytochemicals present in the GC-MS analysis 2-tertbutyl-4,6-bis(3,5-di-tert-butyl-4-hydroxybenzyl)phenol (38.84) was the major compound, followed by cyclo\{tetra[(5-t-butyl-2-hydroxy-1,3phenylene)methylene]\}(15.72\%) not reported for its pharmacological properties. The next successive compound 4H-pyran-4-one, 2,3-dihydro3,5-dihydroxy-6-methyl- (9.34\%) was reported for many pharmacological properties including antioxidant properties [26-28].
All the other phytocompounds such as Bicyclo[3.3.1]nona-3,7-diene2,9-dione (6.25\%), Methyl Ester Of Bicyclo[4.3.0]Non-1(6)-En-4,7Dione-8- (5.66\%), Hexadecanoic acid (2.04\%), 6-Oxoheptanoic acid (1.53\%), 1,2,3-Propanetriol, 1-acetate (1.46\%), 2-Hexanone, 3-methyl-4-methylene- (1.45\%), 2,3-Dihydro-Benzofuran - (1.35\%), 4-((1E)-3-Hydroxy-1-propenyl)-2-methoxyphenol (1.32\%), 4-[4-Chlorophenyl]-N-[2-[1-methyl-2-pyrrolidinyl] ethyl]-6[trichloromethyl]-2-pyrimidine (1.14\%), 2-Methoxy-4-vinylphenol (1.14\%), 2-Hexadecen-1-ol, 3,7,11,15-tetramethyl-, [R-[R*, R*(E)]]- (1.12\%), Benzaldehyde, 2-hydroxy-6-methyl- (0.98\%), rac2,4-Dimethyl-3-nitrobicyclo[3.2.1] octan-8-one (0.96\%), Stigmast5-en-3-ol, (3.beta.,24S)- (0.95\%), Acetic acid, (2-isopropenyl cyclopentylidene)-, methyl ester (0.83\%), 2,4-Dimethyl-3nitrobicyclo[3.2.1] octan-8-one $\quad(0.78 \%), 2(3 \mathrm{H})$-Naphthalenone, 4,4a,5,6-tetrahydro- (0.77\%), 2-Methyl-5-(4-methylphenyl)tetrazole $(0.71 \%), \quad 2$-Furancarboxaldehyde, 5-(hydroxymethyl)- (0.66\%), Hexadecanoic acid, 2-hydroxy-1-(hydroxymethyl)ethyl ester (0.62), 2,4-Dihydroxy-2,5-dimethyl-3(2H)-furan-3-one (0.53\%), 2,5-Dimethyl- 


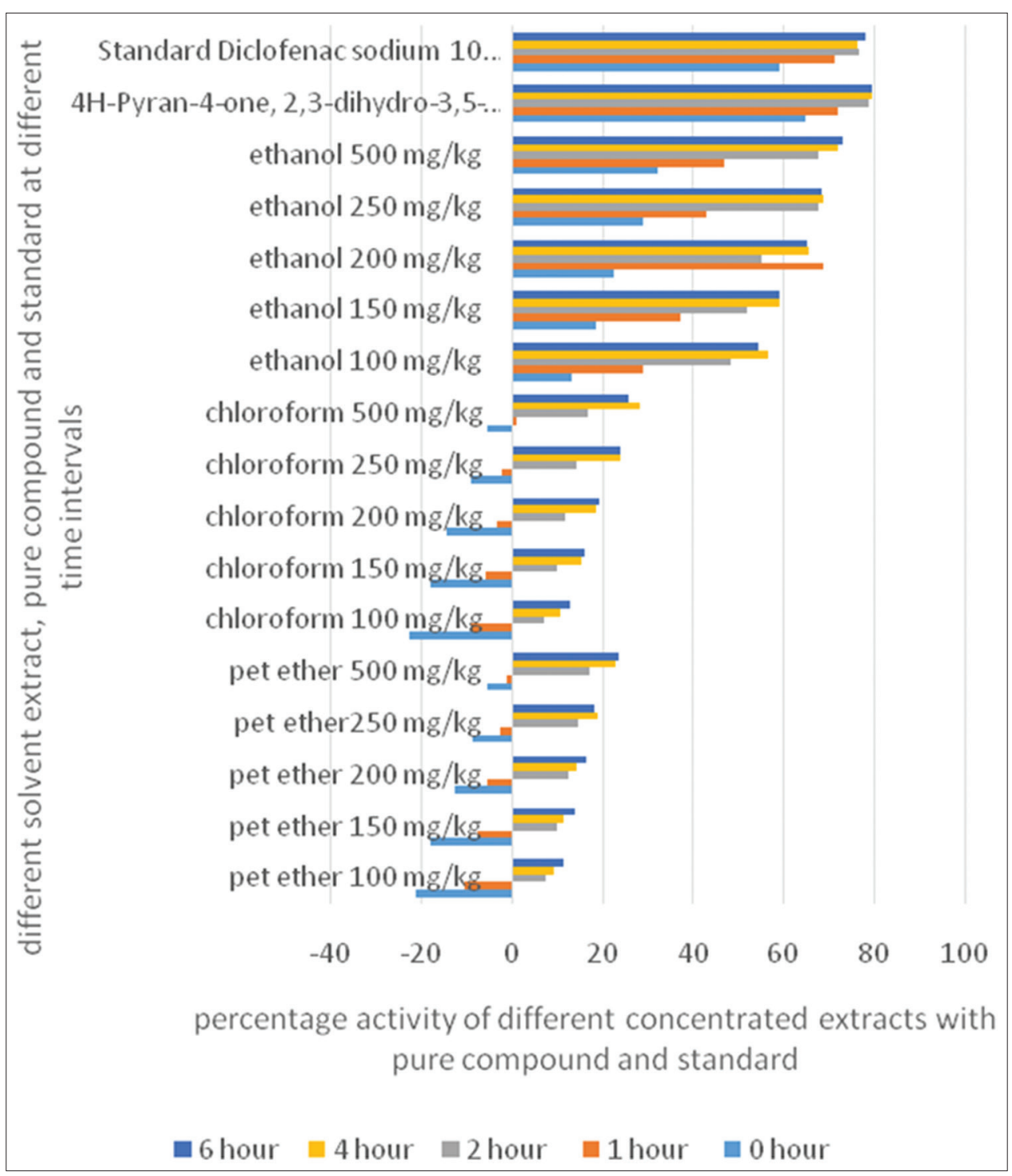

Fig. 23: Percentage inflammation inhibition of different solvent extracts of Pavetta crassicaulis Bremek flower at different concentration at different time intervals

4-hydroxy-3(2H)-furanone (0.52\%), 2,6,10,14,18,22-Tetracosahexaene, 2,6,10,15,19,23-hexamethyl$(0.52 \%)$ Benzaldehyde,

4-hydroxy- $(0.47 \%), 1,5$-Diazocine, octahydro-1,5-dinitro- $(0.4 \%)$, Phenol, 2-methoxy-4-(2-propenyl)- (0.39\%), Octanal, 7-methoxy3,7-dimethyl- (0.37\%), 9,12-Octadecadienoic acid (Z,Z)-, 2-hydroxy-1- (0.3\%), Hexadecanoic acid, methyl ester (0.29\%), 9,12,15-Octadecatrienoic acid, methyl ester, (Z,Z,Z)- (0.28\%) were present in a meager percentage have reported for many medical as well as pharmacological properties (Table 2 and Fig. 2).

Flower ethanolic crude extract was subjected to GC-MS revealed the presence of 39 compounds (Table 3 and Fig. 5). Among all the confirmed phytochemicals, 31 compounds reported for many medicinal and pharmacological properties and 8 compounds activity was not reported.

Among the phytochemicals present in the flower ethanolic extract, 4H-pyran-4-one, 2,3-dihydro-3,5-dihydroxy-6-methyl- (13.82\%), Benzaldehyde, 2-methyl- (7.25\%), Benzaldehyde, 2-methyl-6 hydroxy (6.52\%), 2-Furancarboxaldehyde, 5-(hydroxymethyl)- (6.3\%), were the major compounds. The major compound 4H-Pyran-4-one, 2,3-dihydro-3,5-dihydroxy-6-methyl-was previously report for its antioxidant and other pharmacological properties [27-29], Benzaldehyde, 2-methyl-, Benzaldehyde, 2-methyl- 6 hydroxy, 2-Furancarboxaldehyde, 5-(hydroxymethyl)- were commonly used in food and perfume industry as a flavoring agent $[44,45,62]$.

The rest of the compound present in the GC-MS analysis of flower ethanolic extract was Methyl Ester of Bicyclo[4.3.0]Non-1(6)En-4,7-Dione-8- (4.77\%), 1,2-Benzenediol (4.33\%), Alpha.-DGlucopyranose, 4-O-.beta.-D-galactopyranosyl- (3.95\%), Benzofuran, 2,3-dihydro- (3.5\%), N-Hexadecanoic Acid (3.11\%), $\beta$-Sitosterol (3.1\%), 1,2,3-Propanetriol, diacetate (3\%), 9,12-Octadecadienoic acid (Z,Z)-, 2-hydroxy-1- (2.75\%), 2,6-Dimethyl-4-hydroxybenzaldehyde $(2.73 \%)$, 2-Methoxy-4-vinylphenol (2.58\%), Hexadecanoic acid, 2-hydroxy-1-(hydroxymethyl)ethyl ester (2.57\%), 4-((1E)-3-Hydroxy1-propenyl)-2-methoxyphenol (2.57\%), 9,12,15-Octadecatrienoic acid, methyl ester, (Z,Z,Z)- (2.38\%), Benzaldehyde, 4-hydroxy- (2.3\%), Acetic acid, 1-(2-methyltetrazol-5-yl)ethenyl ester (2.15\%), Benzoyl. beta.-d-glucoside (2.13\%), 2,5-Dimethyl-4-hydroxy-3(2H)-furanone (1.99\%), Benzoic acid, ammonium salt (1.62\%), 2,4-Dihydroxy2,5-dimethyl-3(2H)-furan-3-one $\quad(1.4 \%), \quad$ cis,cis,cis-7,10,13Hexadecatrienal (1.34\%), 9,12-Octadecadienoic acid, methyl ester (1.29\%), Hexadecanoic acid, methyl ester (1.11\%), 2,2-Dimethyl-3-[3methyl-5-(phenylthio)pent-3-enyl]oxirane (1.06\%), Butanedioic acid, monomethyl ester (0.9\%), Tricyclo[7.1.0.0[1,3]]decane-2-carbaldehyde 
(0.88\%), 2,4-Dimethyl-3-nitrobicyclo[3.2.1]octan-8-one (0.85\%), Hexatriacontane $(0.8 \%)$, Campesterol $(0.8 \%)$, 2-acetyl-2-hydroxy-. gamma.-butyrolactone $(0.73 \%), \quad 2(3 \mathrm{H})$-Naphthalenone, $\quad 4,4 \mathrm{a}, 5,6$ tetrahydro- $(0.62 \%)$, Neophytadiene $(0.62 \%)$, Stigmasterol $(0.62 \%)$, $\mathrm{N}, \mathrm{N}$ '-Dimethylpiperazine $(0.6 \%), \quad 2,6,10,14,18,22$-Tetracosahexaene, $2,6,10,15,19,23$-hexamethyl- $\quad(0.56 \%), \quad 1$-Butanamine, 2-methyl$\mathrm{N}$-(2-methylbutylidene)- (0.48\%) in meager quantity has many pharmacological properties were reported (Table 3 and Fig. 5).

The pure compounds showed excellent inflammation suppression activity in that, 2-tert-butyl-4,6-bis(3,5-di-tert-butyl-4-hydroxybenzyl) phenol showed $75.88 \%$ average edema suppression and 4H-Pyran4-one,2,3-dihydro-3,5-dihydroxy-6-methyl- $72.24 \%$ average edema suppression respectively which is almost equal to the $75.94 \%$ average edema suppression.

Some of the researchers used different methods of anti-inflammatory activity such as croton oil-induced ear edema in rats [80,81], protein denaturation bioassay [82-86], membrane stabilization assay using human red blood cell $[87,88]$, but most of the researchers followed carrageenan-induced rat paw edema [89-93] to evaluated antiinflammatory activity.

The results obtained from the above experiments, the ethanolic leaf and flower extracts of P. crassicaulis Bremek. showed excellent inflammation suppression activity, in that leaf ethanolic extract showed good inflammation suppression compared with the flower ethanolic extract. GC-MS analysis both ethanolic crude extracts revealed the presence of 33 and 39 compounds, respectively, in that major compounds were 2-TertButyl-4,6-Bis(3,5-Di-Tert-Butyl-4-Hydroxybenzyl)Phenol (38.84\%) and 4H-Pyran-4-one,2,3-dihydro-3,5-dihydroxy-6-methyl- (13.82\%) respectively.

The extracted pure compounds 2-tert-butyl-4,6-bis(3,5-di-tertbutyl-4-hydroxybenzyl)phenol and 4H-pyran-4-one,2,3-dihydro-3,5dihydroxy-6-methyl- showed excellent anti-inflammation activity almost comparable to the standard diclofenac used.

The pure compound extracted from flower ethanolic extract 4H-pyran4-one,2,3-dihydro-3,5-dihydroxy-6-methyl- [27-29] was previously confirmed for its positive inflammation suppression activity and the pure compound extracted from leaf ethanolic extract 2-tert-butyl-4,6bis(3,5-di-tert-butyl-4-hydroxybenzyl)Phenol is the new report in antiinflammatory activity.

2-tert-butyl-4,6-bis(3,5-di-tert-butyl-4-hydroxybenzyl)Phenol isolated from leaf is excellent inflammation suppressor in compared with the 4H-pyran-4-one,2,3-dihydro-3,5-dihydroxy-6-methyl- extracted from flower ethanolic extract and the crude extracts were also showed the same activity which was also influence by the quantity of compound present in both ethanolic extracts (2-tert-butyl-4,6-bis(3,5-di-tertbutyl-4-hydroxybenzyl)phenol - 38.84\% and 4H-pyran-4-one,2,3dihydro-3,5-dihydroxy-6-methyl- 13.82\% in GC-MS analysis).

In the crude extracts minor compound in little quantity may also influence the activity, if major compound confirms the positive effect, then its influence is more in the activity. In our experiments, both the extracted pure compound showed positive effect in suppressing inflammation.

After administration of crude extracts in tested animals were showed effective in suppressing the inflammation from $0 \mathrm{~h}$ and in next successive hours, these extracts maintain its effectiveness till the last testing hour $(6 \mathrm{~h})$.

\section{CONCLUSION}

The present study shows that the leaf and flower ethanolic crude extracts have remarkable anti-inflammatory activity compared to both petroleum ether and chloroform extracts. The pure compound
2 -tert-butyl-4,6-bis(3,5-di-tert-butyl-4-hydroxybenzyl)phenol extracted from leaf ethanolic crude extract and 4H-pyran-4-one,2,3dihydro-3,5-dihydroxy-6-methyl- extracted from flower ethanolic extract has excellent anti-inflammatory activity which is almost equal to the standards diclofenac sodium used. These results confirm positive activity of the plant as therapeutic agent in tribal medicine. Thus, P. crassicaulis Bremek. leaf and flower parts could be exploited as a valuable source of anti-inflammatory agent for the pharmaceutical industry.

\section{AKNOWLEDGMENT}

The authors would like to thank Prof. Shanmukh I, HOD, Department of Pharmacy, SCS College of Pharmacy, Harapanahalli, Davanagere, Karnataka, for providing facilities to conduct our experimental work.

\section{AUTHOR'S CONTRIBUTIONS}

Ashwathanarayana $\mathrm{R}$ has collected the data, conducted the experiment, and drafted the article. Dr. Raja Naika, professor, has supervised the experiment and reviewed the article.

\section{CONFLICT OF INTEREST}

None.

\section{REFERENCES}

1. Mhaskar KS, Blatter E, Caius JF. In: Kirtikar and Basu's Illustrated Indian Medicinal Plants Their Usage in Ayurveda and Unani Medicine. Vol. 3. Delhi: Shri Satguru Publication; 2000. p. 656-9.

2. Chopra RN, Nayar SL, Chopra IC. Glossary of Indian Medicinal Plants (Publication and Information Directorate. New Delhi: Council of Scientific and Industrial Research; 1956. p. 256-7.

3. Rabe T, Staden JV. Antibacterial activity of South African plants used for medicinal purposes. J Ethnopharmacol 1997;56:81-7.

4. Kamboj VP. Herbal medicine. Curr Sci 2000;78:10.

5. Wikipedia-Western Ghats. Available from: https://www.en.wikipedia. org/wiki/Western Ghats.

6. Manikandan R, Lakshminarasimhan P. Flowering plants of Rajiv Gandhi (Nagarahole) national park, Karnataka, India. Check List 2012;8:1052-84.

7. Jayant K, Mehta P. A study of status, distribution, and dynamics of private and community forests in Sahyadri-Konkan corridor of Maharashtra Western ghats. Technical Report Submitted to CEPFATREE. Pune: Wildlife Research and Conservation Society; 2013. p. 161-3.

8. Bhise MR, Rahangdale SS, Rahangdale SR, Kambhar SV. Floristic study of kalbhairavanatha sacred grove, Terungan, Ambegaon Taluka, Pune. Res Rev J Bot 2013;2:17-24

9. Roy PS, Kushwaha SP, Murthy MS, Kushwaha D, Reddy CS, Behera MD, et al. Biodiversity Characterization at Landscape Level: National Assessment. Dehradun, India: Indian Institute of Remote Sensing (IIRS); 2012. p. 140.

10. Faude U. Human Induced Fragment Formation and Vascular Plants Species Diversity: A Case Study of Satkosia Gorge Wildlife Sanctuary and its Surroundings, Orissa, India, Department of Geography of the Rheinische Friedrich-Wilhelms-University. Bonn, Germany: Foundation for Ecological Security; 2008. p. 52-64

11. Trivedi PC. Medicinal plants utilization and conservation. In: Silori CS, Dixit, AM, Gupta L, Mistry N, editors. Observations on Medicinal Plant Richness and Associated Conservation Issues in District Kachchh, Gujarat. $2^{\text {nd }}$ ed. Jaipur, India: Aavishkar Publishers; 2009. p. 165.

12. Singh P, Ali SJ. Ethno medicinal plants of family Rubiaceae of eastern Uttar Pradesh. Indian J Life Sci 2012;1:83-6.

13. Mishra MK. Biodiversity, traditional knowledge and village ecosystem sustainability. Ecoscan 2013;3:235-40.

14. Ayurvedic Plants Database of Chhattisgarh, India. Available from: http://www.pankajoudhia.com/mpd .pdf

15. Kar A, Bora D, Borthakur SK, Goswami NK, Saharia, D. Wild edible plant resources used by the Mizos of Mizoram, India. Kathmandu Univ J Sci Eng Technol 2013;9:106-26.

16. Kantamreddi VS, Lakshmi YN, Kasapu VV. Preliminary phytochemical analysis of some important Indian plant species. Int J Pharm BioSci $2010 ; 1: 351-8$ 
17. Ashwathanarayana R, Naika R. Preliminary phytochemical and antimicrobial properties of Pavetta crassicaulis Bremek. flower extracts collected from Western Ghats, Karnataka, India. J Pharmacogn Phytochem 2016;5:256-62

18. De Castro MD, García-Ayuso LE. Soxhlet extraction of solid materials: An outdated technique with a promising innovative future. Anal Chim Acta 1998;369:1.

19. Ajaiyeoba EO. Phytochemical and antimicrobial studies of Gynandropsis gynandra and Buchholzia coriaceae extracts. Afr J Biomed Res 2000;3:161-5.

20. Harborne JB. Phytochemical Methods: A Guide to Modern Techniques of Plant Analysis.3 ${ }^{\text {rd }}$ ed. New York: Chapman and Hall Co.; 1998. p. 1-302.

21. Harborne JB. Phytochemical Methods: A Guide to Modern Techniques of Plant Analysis. London: Chapman and Hall Ltd.; 1973. p. 49-188.

22. Tswett M. Adsorption analysis and chromatographic method. Application to the chemistry of chlorophyll. Ber Deutsch Botanischen Ges 1906;24:384-93.

23. Winter CA, Risley EA, Nuss GW. Carrageenan-induced oedema in the hind paw of rat as an assay for anti-inflammatory activity. Proc Soc Exp Biol Ther 1962;111:544-7.

24. Adeyemi OO, Okpo SO, Ogunti OO. Analgesic and anti-inflammatory effect of the aqueous extract of leaves of Persea americana Mill (Lauraceae). Fitoterapia 2002;73:375-80.

25. Bamgbose SO, Noamesi BK. Studies on cryptolepine II: Inhibition of carrageenan induced oedema by cryptolepine. Planta Med 1981:41:392-6.

26. Duffy JC, Dearden JC, Rostron C. Design, synthesis and biological testing of a novel series of anti-inflammatory drugs. J Pharm Pharmacol 2001;53:1505-14.

27. Hiramoto K, Nasuhara A, Michikoshi K, Kato T, Kikugawa K. DNA strand-breaking activity and mutagenicity of 2,3-dihydro-3,5dihydroxy-6-methyl-4H-pyran-4-one (DDMP), a Maillard reaction product of glucose and glycine. Mutat Res Genet Toxicol Environ Mutagen 1997;395:47-56.

28. Kumar PP, Kumaravel S, Lalitha C. Screening of antioxidant activity, total phenolics and GC-MS study of Vitex negundo. Afr J Biochem Res 2010;4:191-5.

29. Yu X, Zhao M, Liu F, Zeng S, Hu J. Identification of 2,3-dihydro-3,5dihydroxy-6-methyl-4H-pyran-4-one as a strong antioxidant in glucosehistidine Maillard reaction products. Food Res Int 2013;51:397-403.

30. PubChem - A Database of Chemicalmolecules and their Activities against Biological Assays, Maintained by the National Center for Biotechnology Information (NCBI). Compound name and Search Page - 2,4-Dihydroxy-2,5-dimethyl-3(2H)-furan-3-one. Available from: https://www.pubchem.ncbi.nlm.nih.gov/compound/538757.

31. Rodin JO, Himel CM, Silverstein RM, Leeper RW, Gortner WA. Volatile flavor and aroma components of pineapple. 1. Isolation and tentative identification of 2, 5-dimethyl-4-hydroxy-3(2h)-furanone. J Food Sci 1965;30:280-5.

32. Bijekar SR, Gayatri MC, Rajanna L. GC-MS profile of methanolic leaf extract of Baliospermum montanum (Wild.) Muell. Arg. Int J Innov Res Sci Eng Technol 2015;4:1-9.

33. Pubchem - A Database of Chemicalmolecules and their Activities against Biological Assays, Maintained by the National Center for Biotechnology Information (NCBI): Home Page - Compound name and Search Page - 2,3-Dihydrobenzofuran. Available from: https://www. pubchem.ncbi.nlm.nih.gov/compound/2 3-dihydrobenzofuran.

34. Gopalakrishnan S, Vadivel E. GC-MS analysis of some bioactive constituents of Mussaenda frondosa Linn. Int J Pharm BioSci 2014;2:312-20.

35. Pubchem - A Database of Chemicalmolecules and their Activities against Biological Assays, Maintained by the National Center for Biotechnology Information (NCBI): Home Page - Compound Name and Search Page - 2-Furancarboxaldehyde,5-(hydroxymethyl). Available from: https://www.pubchem.ncbi.nlm.nih.gov/compound/5hydroxymethylfurfural.

36. Xu C, Ou J, Cui Y, Wang L, Lv C, Liu K, et al. Development of a monoclonal antibody-based enzyme-linked immunosorbent assay for Tetrabromobisphenol A. Monoclonal Antibodies Immunodiagn Immunother 2013;32:113-8.

37. Pubchem - A Database of Chemicalmolecules and their Activities against Biological Assays, Maintained by the National Center for Biotechnology Information (NCBI): Home Page - Compound Name and Search Page - Benzaldehyde, 4-hydroxy. Available from: https:// www.pubchem.ncbi.nlm.nih.gov/compound/4-hydroxybenzaldehyde.
38. Pubchem - A Database of Chemicalmolecules and their Activities against Biological Assays, Maintained by the National Center for Biotechnology Information (NCBI): Home Page - Compound Name and Search Page - 2-Methoxy-4-vinylphenol. Available from: https://www. pubchem.ncbi.nlm.nih.gov/compound/2-Methoxy-4-vinylphenol.

39. Jeong JB, Hong SC, Jeong HJ, Koo JS. Anti-inflammatory effect of 2-methoxy-4-vinylphenol via the suppression of $\mathrm{NF}-\mathrm{\kappa B}$ and MAPK activation, and acetylation of histone H3. Arch Pharm Res 2011;34:2109.

40. Silici S, Kutluca S. Chemical composition and antibacterial activity of propolis collected by three different races of honeybees in the same region. J Ethnopharmacol 2005;99:69-73.

41. Pubchem - A Database of Chemicalmolecules and their Activities against Biological Assays, Maintained by the National Center for Biotechnology Information (NCBI): Home Page - Compound Name and Search Page - Phenol, 2-methoxy-4-(2-propenyl). Available from: https://www.pubchem.ncbi.nlm.nih.gov/compound/eugenol.

42. Kabuto H, Tada MM, Kohno M. Eugenol [2-methoxy-4-(2-propenyl) phenol] prevents 6-hydroxydopamine- induced dopamine depression and lipid peroxidation inductivity in mouse striatum. Biol Pharm Bull 2007;30:423-7.

43. Chen Y, Zhou C, Ge Z, Liu Y, Liu Y, Feng W, et al. Composition and potential anticancer activities of essential oils obtained from myrrh and frankincense. Oncol Lett 2013;6:1140-6.

44. Hussain N, Abbasi T, Abbasi SA. Transformation of the pernicious and toxic weed parthenium into an organic fertilizer by vermicomposting. Int J Environ Stud 2016;73:731-45.

45. Leal WS, Nakano Y, Kuwahara Y, Nakao H, Suzuki T. Pheromone study of acarid mites XVII: Identification of 2-hydroxy-6-methyl benzaldehyde as the alarm pheromone of the acarid mite Tyrophagus perniciosus (Acarina: Acaridae), and its distribution among related mites. Appl Entomol Zool 1988;23:422-7.

46. Kuwahara Y, Sato M, Koshii T, Suzuki T. Chemical ecology of astigmatid mites XXXII.2-hydroxy-6-methyl-benzaldehyde, the sex pheromone of the brown-legged grain mite Aleuroglyphus ovatus (TROUPEAU) (Acarina: Acaridae). Appl Entomol Zool 1992;27:253-60.

47. Pubchem - A Database of Chemicalmolecules and their Activities against Biological Assays, Maintained by the National Center for Biotechnology Information (NCBI): Home Page - Compound Name and Search Page - 2-Hexadecen-1-ol, 3,7,11,15-tetramethyl-, [R-[R*,R*-(E)]]. Available from: https://www.pubchem.ncbi.nlm.nih. gov/compound/5366244.

48. Olofsson P, Holmberg J, Tordsson J, Lu S, Åkerström B, Holmdahl R. Positional identification of Ncfl as a gene that regulates arthritis severity in rats. Nat Genet 2003;33:25-32.

49. Pubchem - A Database of Chemicalmolecules and their Activities against Biological Assays, Maintained by the National Center for Biotechnology Information (NCBI): Home Page - Compound Name and Search Page - Hexadecanoic Acid, Methyl Ester. Available from: https://www.pubchem.ncbi.nlm.nih.gov/compound/methyl palmitate.

50. Pubchem - A Database of Chemicalmolecules and their Activities against Biological Assays, Maintained by the National Center for Biotechnology Information (NCBI): Home Page - Compound Name and Search Page - Hexadecanoic Acid. Available from: https://www. pubchem.ncbi.nlm.nih.gov/compound/palmitic acid.

51. Yff BT, Lindseya KL, Taylor MB, Erasmus DG, Jäger AK. The pharmacological screening of Pentanisia prunelloides and the isolation of the antibacterial compound palmitic acid. J Ethnopharmacol 2002;79:101-7.

52. Gnanavel V, Sara AM. GC-MS analysis of petroleum ether and ethanol leaf extracts from Abrus precatorius LINN. Int $\mathrm{J}$ Pharm BioSci 2013;4:37-44

53. Jananie RK, Priya V, Vijayalakshmi K. Determination of bioactive components of Cynodon dactylon by GC-MS analysis. N Y Sci J 2011;4:16-20.

54. Sudha T, Chidambarampillai S, Mohan VR. GC-MS analysis of bioactive components of aerial parts of Fluggea leucopyrus Willd. (Euphorbiaceae). J Appl Pharm Sci 2013;3:126-30

55. Mujeeb F, Bajpai P, Pathak N. Phytochemical evaluation, antimicrobial activity and determination of bioactive components from leaves of Aegle marmelos. BioMed Res Int 2014;1:1-11.

56. Chemical Land 21 - Website Gives Chemical Properties of few Natural and Synthetic Compound - Compound Name and Search Page - N,N'Dimethylpiperazine. Available from: http://www.chemicalland21.com/ specialtychem/perchem/n,n'-DIMETHYLPIPERAZINE.htm.

57. Pubchem - A Database of Chemicalmolecules and their Activities against Biological Assays, Maintained by the National Center for 
Biotechnology Information (NCBI): Home Page - Compound Name and Search Page - Acetic Acid, 1-(2-methyltetrazol-5-yl) Ethenyl Ester. Available from: https://www.pubchem.ncbi.nlm.nih.gov/compound/ ethyl acetate.

58. Pubchem - A Database of Chemicalmolecules and their Activities against Biological Assays, Maintained by the National Center for Biotechnology Information (NCBI): Home Page - Compound Name and Search Page - Butanedioic Acid, Monomethyl Ester. Available from: https://www.pubchem.ncbi.nlm.nih.gov/compound/22292473.

59. Pubchem - A Database of Chemicalmolecules and their Activities against Biological Assays, Maintained by the National Center for Biotechnology Information (NCBI): Home Page. Compound Name and Search Page - Benzoic Acid, Ammonium Salt. Available from: https:// www.pubchem.ncbi.nlm.nih.gov/compound/10920587.

60. Pubchem - A Database of Chemicalmolecules and their Activities against Biological Assays, Maintained by the National Center for Biotechnology Information (NCBI): Home Page: Compound Name and Search Page - 1,2-Benzenediol. Available from: https://www.pubchem. ncbi.nlm.nih.gov/compound/catechol.

61. Xu N, Fan X, Yan X, Li X, Niu R, Tseng CK. Antibacterial bromophenols from the marine red alga Rhodomela confervoides. Phytochemistry 2003;62:1221-4.

62. Pubchem - A Database of Chemicalmolecules and their Activities against Biological Assays, Maintained by the National Center for Biotechnology Information (NCBI): Home Page - Compound Name and Search Page - Benzofuran,2,3-dihydro. Available from: https:// www.pubchem.ncbi.nlm.nih.gov/compound/2_3-dihydrobenzofuran.

63. Muratore G, Licciardello F, Restuccia C, Puglisi ML, Giudici P. Role of different factors affecting the formation of 5-hydroxymethyl2 -furancarboxaldehyde in heated grape must. J Agric Food Chem 2006:54:860-3

64. Pubchem - A Database of Chemicalmolecules and their Activities against Biological Assays, Maintained by the National Center for Biotechnology Information (NCBI): Home Page - Compound Name and Search Page - 1,2,3-Propanetriol, Diacetate. Available from: https:// www.pubchem.ncbi.nlm.nih.gov/compound/3-Hydroxypropane-1_2diyl diacetate.

65. Pubchem - A Database of Chemicalmolecules and their Activities against Biological Assays, Maintained by the National Center for Biotechnology Information (NCBI): Home Page - Compound Name and Search Page - Benzaldehyde, 2-Methyl. Available from: https:// www.pubchem.ncbi.nlm.nih.gov/compound/2-Methylbenzaldehyde.

66. Pubchem - A Database of Chemicalmolecules and their Activities against Biological Assays, Maintained by the National Center for Biotechnology Information (NCBI): Home Page - Compound Name and Search Page - 2,6-Dimethyl-4-hydroxybenzaldehyde. Available from: https://www.pubchem.ncbi.nlm.nih.gov/compound/2 6Dimethyl-4-hydroxybenzaldehyde.

67. Guerin MR, Olerich G. Gas chromatographic determination of neophytadiene as a measure of the terpenoid contribution to experimental tobacco smoke carcinogenesis. Environ Lett 1975;10:265-73.

68. Sermakkani M, Thangapandian V. GC-MS Analysis of Cassia italica leaf methanol extract. Asian J Pharm Clin Res 2012;5:90-4.

69. Pubchem - A Database of Chemicalmolecules and their Activities against Biological Assays, Maintained by the National Center for Biotechnology Information (NCBI): Home Page - Compound Name and Search Page - 9,12-Octadecadienoic Acid, Methyl Ester. Available from: https://www.pubchem.ncbi.nlm.nih.gov/compound/Methyl linolelaidate.

70. Pubchem - A Database of Chemicalmolecules and their Activities against Biological Assays, Maintained by the National Center for Biotechnology Information (NCBI): Home Page - Compound Name and Search Page - Alpha.-D-Glucopyranose, 4-O-.beta.-Dgalactopyranosyl. Available from: https://www.pubchem.ncbi.nlm.nih. gov/compound/441014.

71. Abdallah DJ, Sirchio SA, Weiss RG. Hexatriacontane organogels. The first determination of the conformation and molecular packing of a low-molecular-mass organogelator in its gelled state. Langmuir 2000;16:7558-61.
72. Pubchem - A Database of Chemicalmolecules and their Activities against Biological Assays, Maintained by the National Center for Biotechnology Information (NCBI): Home Page - Compound Name and Search Page - Campesterol. Available from: https://www.pubchem. ncbi.nlm.nih.gov/compound/campesterol.

73. Villaseñor IM, Angelada J, Canlas AP, Echegoyen D. Bioactivity studies on $\beta$-sitosterol and its glucoside. Phytother Res 2002;16:417-21.

74. Loizou S, Lekakis I, Chrousos GP, Moutsatsou P. $\beta$-Sitosterol exhibits anti-inflammatory activity in human aortic endothelial cells. Mol Nutr Food Res 2010;54:551-8

75. Awada AB, Chinnam M, Finka CS. Bradford PG. $\beta$-sitosterol activates fas signaling in human breast cancer cells. Phytomedicine 2007; $14: 747-54$

76. Gupta R, Sharma AK, Dobhal MP, Sharma MC, Gupta RS. Antidiabetic and antioxidant potential of $\beta$-sitosterol in streptozotocin-induced experimental hyperglycemia. J Diabetes 2011;3:29-37.

77. Grundy SM, Ahrens EH Jr, Salen G. Dietary $\beta$-sitosterol as an internal standard to correct for cholesterol losses in sterol balance studies. J Lipid Res 1968;9:374-87.

78. Gupta MB, Nath R, Srivastava N, Shanker K, Kishor K, Bhargava KP. Anti-inflammatory and antipyretic activities of $\beta$-sitosterol. Planta Med 1980;39:157-63.

79. Dr Duke's Phytochemical and Ethnobotanical Databases. U.S. Department of Agriculture, Agricultural Research Service; 1992-2016. Available from: http://www.phytochem.nal.usda.gov.

80. Tubaro A, Dri P, Delbello G, Zilli C, Della Loggia R. The croton oil earnest revisited. Agents Actions 1986;17:347-9.

81. Zaouani M, Bitam A, Baz A, Benali $\mathrm{Y}$, Ben-Mahdi $\mathrm{MH}$. In vivo evaluation of wound healing and anti-inflammatory activity of methanolic extract of roots of Centaurea africana (L.) in topical formulation. Asian J Pharm Clin Res 2017;10:341-6.

82. Mizushima Y, Kobayashi M. Interaction of anti-inflammatory drugs with serum proteins, especially with some biologically active proteins. J Pharm Pharmacol 1968;20:169-73.

83. Sakat $\mathrm{S}$, Juvekar $\mathrm{AR}$, Gambhire $\mathrm{MN}$. In vitro antioxidant and inflammatory activity of methanol extract of Oxalis corniculata Linn. Int J Pharm Pharm Sci 2010;2:146-55.

84. Annavarapu TR, Renuka P, Akhil P, Divya P, Priyanka PD. Evaluation of the anti-inflammatory activity of combination of ethanol extracts of Azadirachta indica (neem) and Lawsonia inermis (henna). Asian J Pharm Clin Res 2016;9:256-8.

85. Tamiljothi E, Ravichandiran V, Chandrasekhar N, Suba V. Pharmacognostic and preliminary phytochemical screening of leaves of Tecomaria capensis. Asian J Plant Sci Res 2011;1:34-40.

86. Iswariya S, Uma TS. Evaluation of in vitro anti-inflammatory and antimicrobial activity of aqueous and methanolic seed extracts of Citrullus lanatus. Int J Pharm Pharm Sci 2017;9:29-33.

87. Chowdhury A, Azam S, Jainul MA, Faruq KO, Islam A. Antibacterial activities and in vitro anti-inflammatory (membrane stability) properties of methanolic extracts of Gardenia coronaria leaves. Int J Microbiol 2014;2014:1-5.

88. Sutrisno E, Adnyana IK, Sukandar EY, Fidrianny I, Aligita W. Antiinflammatory study of Anredera cordifolia leaves and Centella asiatica herbs and its combinations using human red blood cell-membrane stabilization method. Asian J Pharm Clin Res 2016;9:78-80.

89. Singh A, Malhotra S, Subban R. Anti-inflammatory and analgesic agent from indian medicinal plants. Int J of Integr Biol 2008;3:57-72

90. Vinegar R, Schriber W, Hugo R. Biphasic development of carrageenan induced in rats. J Pharmacol Exp Ther 1969;16:96-103.

91. Jigam AA, Akanya HO, Ogbadoyi EO, Bukar E, Dauda N, Evans EC. In vivo antiplasmodial, analgesic and anti-inflammatory activities of the leaf extract of Lippia multiflora Mold. J Med Plants Res 2009;3:148-54.

92. Lin J, Opoku AR, Geheeb-Keller M, Hutchings AD, Terblanche SE, Jager AK, et al. Preliminary screening of some traditional Zulu medicinal plants for anti-inflammatory and anti-microbial, activities. J Ethnopharmacol 1999;68:267-74.

93. Prabha PM, Kamalakkannan V, Arul Kumaran KS, Sambathkumar R. In-vivo anti-inflammatory activities of ethanolic root extract of Bauhinia variegata Linn. Int J Pharm Pharm Sci 2014;6:445-8. 